Document downloaded from:

http://hdl.handle.net/10251/147433

This paper must be cited as:

Alfalla-Luque, R.; Dominguez Machuca, JA.; Marin-Garcia, JA. (2018). Triple-A and competitive advantage in supply chains: Empirical research in developed countries. International Journal of Production Economics. 203:48-61.

https://doi.org/10.1016/j.ijpe.2018.05.020

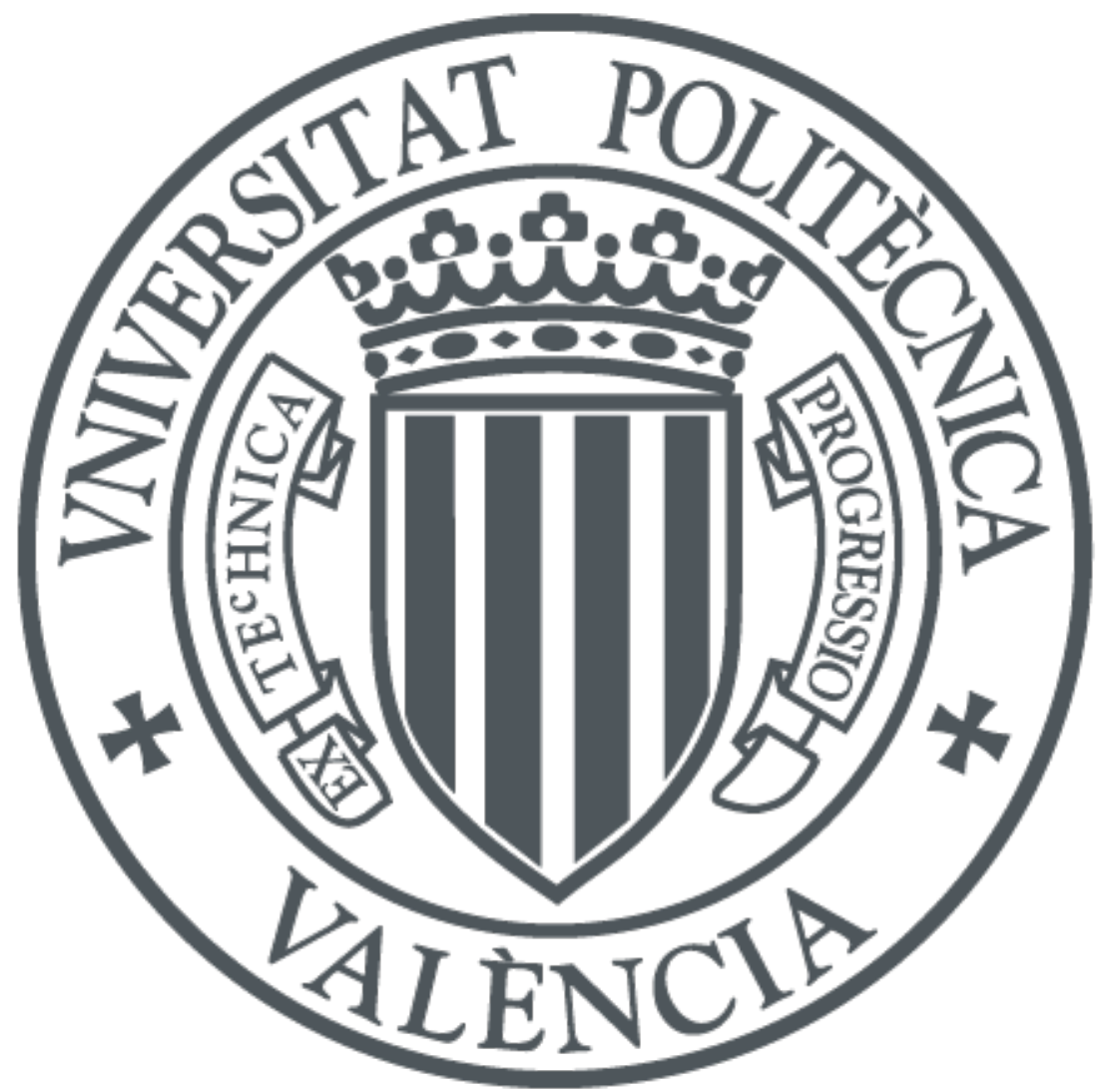

The final publication is available at

https://doi.org/10.1016/j.ijpe.2018.05.020

Copyright Elsevier

Additional Information 


\section{Accepted Manuscript}

Triple-A and competitive advantage in supply chains: Empirical research in developed countries

Rafaela Alfalla-Luque, José A.D. Machuca, Juan A. Marin-Garcia

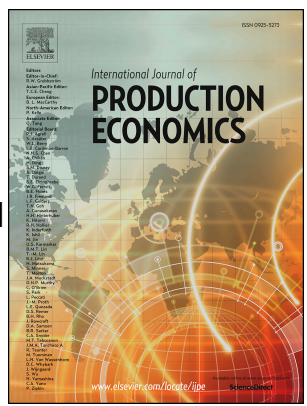

PII:

S0925-5273(18)30222-6

DOI:

10.1016/j.ijpe.2018.05.020

Reference: PROECO 7049

To appear in: International Journal of Production Economics

Please cite this article as: Alfalla-Luque, R., Machuca, J.A.D., Marin-Garcia, J.A., Triple-A and competitive advantage in supply chains: Empirical research in developed countries, International Journal of Production Economics (2018), doi: 10.1016/j.jpe.2018.05.020.

This is a PDF file of an unedited manuscript that has been accepted for publication. As a service to our customers we are providing this early version of the manuscript. The manuscript will undergo copyediting, typesetting, and review of the resulting proof before it is published in its final form. Please note that during the production process errors may be discovered which could affect the content, and all legal disclaimers that apply to the journal pertain. 


\title{
Triple-A and competitive advantage in supply chains: empirical research in developed countries
}

\author{
Rafaela Alfalla-Luque ${ }^{1}$ \\ GIDEAO Research Group, Departamento de Economía Financiera y Dirección de \\ Operaciones \\ Universidad de Sevilla, Spain \\ E-mail: alfalla@us.es \\ José A.D. Machuca \\ GIDEAO Research Group, Departamento de Economía Financiera y Dirección de \\ Operaciones \\ Universidad de Sevilla, Spain \\ E-mail: jmachuca@us.es \\ Juan A. Marin-Garcia \\ ROGLE Research Group \\ DOE Universitat Politècnica de València, Spain \\ E-mail: jamarin@omp.upv.es
}

\footnotetext{
${ }^{1}$ Corresponding author
} 


\title{
Triple-A and competitive advantage in supply chains: empirical research in developed countries
}

\begin{abstract}
:
Based on his own experience in a number of companies, Lee (2004) posits that the Triple-A (agility, adaptability and alignment) is essential for supply chain (SC) management to achieve a sustainable competitive advantage (CA). However, there is a lack of empirical research that analyzes the Triple-A SC and its impacts on CA. The objective of the present work is to address this omission and to provide empirical evidence on this topic using a multiple-informant, international sample from eight developed countries. A consistent partial least squares structural equation model (PLSc) is used on data for 151 manufacturing plants in three industrial sectors to determine whether agility, alignment and adaptability have individual and/or joint effects on achieving a CA in SCs. In relation to the individual effects, different CAs are achieved by each of the Triple-A variables. SC adaptability has been shown to have a significant positive relationship with all the dimensions of CA. SC alignment affects most of these dimensions, but SC agility only affects financial CA and flexibility CA. This research does, however, confirm the positive relationship for the joint effect of the Triple-A SC variables and CA. The effects are significant on all the CA measures except quality. Important implications can be drawn for managers by showing how SC levers can be set to improve performance indicators
\end{abstract}

Keywords:

Agility, adaptability, alignment, competitive advantage, Triple-A, performance

\section{Introduction}

Firms with operations, suppliers and customers located in any part of the world have been forced to seek new ways to manage their operations outside the strict limits of the individual company, and the supply chain (SC) has come under increasing scrutiny. In the struggle to achieve the competitive advantages that enable rapid positioning in the customer's preferences and greater cost-effectiveness, there has been a shift from competition between companies to a framework in which it is the SCs that compete with each other (Ketchen and Hult, 2007; Alfalla-Luque et al., 2013). Competitive advantage (CA) is considered to be a capability developed from a company's attributes and resources that allows the firm to achieve a higher level of performance than the competition (Hayes and Wheelwright, 1984). In a new context of high SC competition, Lee (2004) made a major statement that contrasted with current knowledge on the matter: "Ceteris paribus, companies whose supply chains became more efficient and cost-effective did not gain a sustainable advantage over their rivals'. He asserted that "only supply chains that are agile, adaptable, and aligned provide companies with sustainable competitive advantage".

However, this assessment was based on his professional experience and he conducted no formal empirical research to confirm his hypothesis. In spite of its evident interest in the current SC global context, theory development in this topic has been very limited. When analyzing the literature (see Section 2), it can be observed that there are almost no studies on this topic and that none have analyzed the CA's sustainability. Furthermore, it should be stressed that most studies on the topic have focused on the effect of Triple-A SC variables on different performance measurements (e.g., operational performance, organizational performance, cost 
performance, firm performance, SC performance, etc.) but not on CA indicators. In other words, they do not show any comparison of a company's performance with its main competitors. In this paper, CA measures will be used instead of performance indicators, as they are more relevant for the purpose of this research. Most empirical research examines the separate effects of each of the Triple-A SC variables on performance, showing in general (but not always) positive impacts (by way of example: Blome et al. (2013) for agility; Skipworth et al. (2015) for alignment; and Schoenherr and Swink, 2015 for adaptability). However, as stated by AranaSolares et al. (2011), very few research studies have been done to analyze Triple-A SC variables combinations. In fact, although they have focused on the effect of different pairs of these variables, they have not analyzed their joint effect, but only their individual effects on performance, obtaining mixed results. Finally, with respect to research considering the three Triple-A SC variables, as commented below, the scarcity is patently clear.

Ketchen and Hult (2007) state that Triple-A SCs are distinguishable from traditional SCs by how they approach agility, adaptability and alignment, and by their ability to pursue competitive priorities. Triple-A SCs focus on the total value added to the user, not simply on one of the priorities, such as cost or speed. However, no empirical research is included in this paper. A few other papers include empirical research (e.g., Dubey et al., 2015; Dubey and Gunasekaran, 2016), and analyze the three variables in the same framework and their relationships with performance, but only as individual independent variables. Only two articles have been found that jointly consider the Triple-A SC (as a multidimensional scale) - performance relationship (Attia, 2015; Whitten et al., 2012). In these two cases, the separate effects of the individual Triple-A SC variables on performance are not analyzed. These studies have the limitations that they focus on a single country (Egypt and USA, respectively), take data from single respondents, and use a scale that does not come from an analysis of the previous literature but only from Lee's (2004) theoretical reasoning. In addition, Attia (2015) focuses on a single sector (textiles). Both studies conclude that a positive relationship exists between Triple-A SC and performance but, given their limitations, their authors also coincide in stating that further research needs to be done with multi-informant samples and scales based on a literature analysis in order to confirm their results in different industrial sectors and other countries. Therefore, the lack of empirical evidence to test this statement, which can be judged to be important in the context of increasing SC global competition, calls for more research on this topic.

The present paper seeks to contribute to research on the effects of the Triple-A SC variables by providing new empirical evidence on this topic while overcoming the limitations of previous research. The limited research that exists on the individual Triple-A SC variables, above all on $\mathrm{SC}$ adaptability and alignment, has led to interest in analyzing not only the joint effect of TripleA SC on CA, but also how each of the separate Triple-A SC variables affects the obtention of a $\mathrm{CA}$, which could also be a contribution to this field. In addition, this will indicate whether the obtained results are in the same line as results observed in the prior literature, while also contributing to mitigating the lack of research on what is considered to be a major topic for SC management (SCM). Therefore, this research objective is to determine whether SC agility, alignment and adaptability have individual and/or joint effects on achieving a CA. It has not been possible to test the effects of the Triple-A SC on a "sustainable CA" because the current data are cross sectional and do not allow a longitudinal study. Due to this lack of data to analyze the sustainability component of the $\mathrm{CA}$, the current research has been focused on the relationship of the Triple-A SC with CAs, as the first step required for a company to have a CA is to make sure that it continues to be sustainable in the future. This is the first empirical study 
that focuses on the Triple-A SC - competitive advantage relationship in a worldwide multiple informant sample.

The paper is structured as follows. Section 2 analyzes earlier studies and establishes the hypotheses to be tested. Section 3 describes the sample and the methodology employed. This is followed by the results. Finally, the main conclusions, contributions, implications for practitioners and academics, limitations and future research are presented.

\section{Theoretical background, literature analysis and research hypotheses}

\subsection{Theoretical background}

This paper builds on two frequently identified theories in SCM (Defee et al., 2010), the theoretical base of the resource-based view (RBV) (Peteraf, 1993; Barney, 1991) and the dynamic capabilities view (DCV) (Teece et al., 1997).

According to the RBV, companies are accumulations of resources, some of which can be considered to be strategic (Wernerfelt, 1984); firms have the capacity to generate a CA by developing their own particular resources and capabilities (Barney, 1991; Peteraf, 1993). From the SC point of view, the RBV concept becomes an "extended RBV", as inter-organizational relationships are included as a strategic resource that reaches beyond the limits of the organization (Cousins and Menguc, 2006; Prajogo et al., 2012). Greater and greater interest has been shown in RBV in SCM research (e.g., Reuter et al., 2010; Allred et al., 2011). For example, Ketchen and Hult (2007) state that Triple-A SCs are a reflection of the assumption that unique SC level resources exist and that they are competitive weapons that are impossible for other companies to imitate. In addition, if SCM is considered to be a strategic resource, it requires unique capabilities, whose implementation could be difficult or expensive, and so could lead to CAs and improvements to company performance (Barney, 2012). Thus Triple-A SC is a complex resource that necessitates exclusive capabilities and whose implementation might be difficult or expensive. The capabilities considered in the present research are: SC agility, SC alignment and SC adaptability. Previous research has acknowledged the importance of the RBV focus for SCM and the Triple-A SC variables (Brusset, 2016; Gligor et al., 2016; Kim et al., 2013; Mokadem, 2016; Tuan, 2016, Tse et al., 2016).

From the perspective of the DCV, companies are required to respond to uncertain environments by adapting their SC resources. DCV considers that firms can use their own particular internal and external abilities and know-how and also develop new capacities to contend with changing environments (Teece et al., 1997). Market turbulence is the main cause of environmental changes in the SC context, along with unpredictable market and customer requirements and competitor strategies. Teece's (2007) framework proposes that, just as dynamic capabilities enable opportunities to be perceived, shaped and then seized, and competitiveness maintained through a reconfiguration of company assets, so they can be extended to SCM (Wei and Wang, 2010). In this context, Triple-A SC variables can be thought of as difficult-to-replicate dynamic capabilities that generate CAs and enable companies to boost their level of performance (Asanuma, 1989; Dyer, 1996). 


\subsection{Literature analysis and research hypotheses}

\section{SC Agility}

Agility first emerged as a business concept as part of agile and flexible manufacturing systems (Christopher, 2000). The concept was later extended to a wider business context: organizational/enterprise agility (Sherehi et al., 2007) and SC agility (Christopher and Towill, 2002; Li et al., 2008). Consequently, SC agility is a relatively new construct (Braunscheidel and Suresh, 2009) but has already been recognized as one of SCM's most important capabilities (Christopher and Towill, 2001; Agarwal et al., 2007; Gligor et al., 2016). Ganguly et al. (2009) point out that agility is a major driving force for business and absolutely essential for a firm to be able to survive and thrive in unsettled markets. In today's constantly changing environment, SC agility is identified as a key element of competitiveness ( $\mathrm{Li}$ et al., 2008) that enables a superior position to be gained by responding in a timely and effective way to market volatility and other uncertainties (Power et al., 2001; Swafford et al., 2006; Gligor and Holcomb, 2014). Agility is becoming increasingly important because product life cycles are shrinking and global economic and competitive pressures are leading to additional uncertainty (Baker, 2008; Swafford et al., 2006). Christopher and Towill (2001) and Brusset (2016) state that to survive and prosper in an ever-changing business environment, firms need to enhance their SC agility by implementing the right approach when they configure the SC structure and establish relationships with their partners.

Although the benefits of agility have been widely recognized across a variety of domains, limited empirical research has been developed in the SC context (Gligor and Holcomb, 2012b). The linkage between SC agility and CA is still in its infancy in the literature (Wu et al., 2017) and the published studies on the topic do not show a consensus in their results. Some studies conclude that SC agility has a positive and direct impact on a number of performance indicators, such us: competitive business performance (e.g., Swafford et al., 2008; Yusuf et al., 2014); operational performance (e.g., Blome et al., 2013; Gligor and Holcomb, 2012a; Eckstein et al., 2015); organizational performance (e.g., Khan and Pillania, 2008); relational performance (e.g., Gligor and Holcomb, 2012a); cost performance (e.g., Eckstein et al., 2015); firm performance (e.g., Liu et al., 2013; Tse et al., 2016); SC performance (e.g., Sangari and Razmi, 2015; Kabra and Ramesh, 2016; Dubey and Gunasekaran, 2016); logistics performance (e.g., Dubey et al., 2015); human performance (e.g., Dubey et al., 2015); sales, market share; profitability; speed to market; and customer satisfaction (e.g., DeGroote and Marx, 2013): return on global assets, global market share, profit margins, sales/number of employees (e.g. Yusuf et al., 2004).

However, other studies do not confirm all the positive relationships or show mixed results. For example, Yang (2014) concludes that SC agility has an insignificant direct effect on performance. Um (2016) states that SC agility is not positively related to an organization's business performance (market share and sales growth, ROS and ROA) in a high-level customization environment, but positively influences customer service and differentiation (mediation) to achieve better business performance. Gligor et al. (2015) conclude that SC agility positively impacts the firm's financial results, but this is done in an indirect way by positively impacting its customer effectiveness and cost efficiency (mediating effects). Gligor (2016) does not confirm the direct positive relationship between SC agility and financial performance (ROA). 
As a result, the effect of SC agility is not clear. Scholars have called for more research to understand this topic in greater depth (Gligor and Holcomb, 2012a). As was previously stated, to follow this call, this study will use CA measures rather than performance indicators, as CA is more relevant for the purpose of this research since it compares one company's performance indicators with its main competitors (this measure was what Lee (2004) referred to in his paper). As there is no consensus in the literature, the first hypothesis is proposed in a positive sense, as follows:

\section{H1. SC agility is positively related to $C A$}

Some studies provide formal definitions of SC agility (e.g., Naylor et al., 1999; Swafford et al., 2006; Ismail and Sharifi, 2006, Lin et al., 2006; Arana-Solares et al., 2011). Detailed analyses of agility and SC agility definitions based on extensive literature reviews can be found in Agarwal et al. (2007), Li et al. (2008), Li et al. (2009), Ganguly et al. (2009), Arana-Solares et al. (2011), Gligor and Holcomb (2012b) and Yusuf et al. (2014). Taking into account these previous studies, SC agility can be defined as an SC's ability to rapidly detect and respond to unexpected short-term changes in supply and demand in order to generate or preserve a CA (Arana-Solares et al., 2011), thus allowing companies to remain fully aware of variations in customers' preferences and requirements and offer them the right product at the right time and price (Brusset, 2016). Despite the literature Taking into account the previous research, market sensitivity in the short term and response to market changes (volume and variety flexibility) are what generate the dimensions of SC agility considered in this empirical research (see Table 1).

\begin{tabular}{|l|l|l|}
\hline Code & Variable and dimensions & Definition \\
\hline SC-Ag & Supply chain agility & $\begin{array}{l}\text { Ability to rapidly detect and respond to short-term changes in } \\
\text { demand and supply. }\end{array}$ \\
\hline SC-Ag1 & $\begin{array}{l}\text { Short-term sensitivity to } \\
\text { market }\end{array}$ & $\begin{array}{l}\text { Ability to rapidly detect short-term changes in demand and } \\
\text { supply. }\end{array}$ \\
\hline SC-Ag2 & Volume flexibility & $\begin{array}{l}\text { Ability to rapidly respond to short-term changes in demand and } \\
\text { supply by adapting product volumes. }\end{array}$ \\
\hline SC-Ag3 & Variety flexibility & $\begin{array}{l}\text { Ability to rapidly respond to short-term changes in demand and } \\
\text { supply by adapting the product range. }\end{array}$ \\
\hline
\end{tabular}

Table 1. SC agility definitions and dimensions

\section{SC Adaptability}

The SC also has to address any long-term structural changes that might occur. These include economic development, political and social change, demographic trends, changes in consumer habits and technological advances in the various regions and countries. As is the case with agility, the concept of adaptability has its roots in the manufacturing area and later came to spread throughout the company as a whole. Several research studies have been developed that focus on manufacturing and firm adaptability (Bordoloi et al., 1999; Katayama and Bennett, 1999; Sonntag, 2003; Tan and Tiong, 2005). Touminen et al. (2004) state that in a turbulent and complex business environment, adaptability seems to be one of the key prerequisites for good performance and a source of a sustainable CA. Uncertainty is present in the global context. To be successful, organizations must constantly adapt to their environments through suitable strategy and organizational structure (Gibbons et al., 2003), while taking into account technology and market focuses (Touminen et al., 2004; Arana-Solares et al., 2011). 
Despite the literature acknowledging the importance of SC adaptability, limited research has been conducted into this variable. Some studies show that SC adaptability can result in significant cost savings and high customer demand fill rate (e.g., Dubey et al., 2015; Chan and Chan, 2010). Schoenherr and Swink (2015) stress the core role that this variable plays in capturing the benefits of supplier technological intelligence for enhanced product innovation capability, new product launch success, and firm financial performance. Eckstein et al. (2015) conclude that SC adaptability has a positive effect on cost performance and on operational performance. Some papers have been developed in the context of the humanitarian SC: although Kabra and Ramesh (2016) conclude that SC adaptability is not positively related to performance, Dubey and Gunasekaran (2016) state that SC adaptability is positively linked to humanitarian SC performance. Again, in view of the scarce works on this topic, there is a need for more research in this area and to focus on CA. As a contribution to the discussion, the following hypothesis has been proposed in a positive sense in the search for new empirical evidence:

\section{H2. SC adaptability is positively related to $C A$}

Lee (2004) stated that adaptation is required when structural changes take place in the markets and indicates two key components for an adaptable SC: the ability to identify trends and the capability to change supply networks. For Ketchen and Hult (2007), an adaptable SC relies on information systems to identify shifts in the market, and then take appropriate actions (e.g., moving facilities, changing suppliers, and outsourcing). Reviewing the previous literature, Arana-Solares et al. (2011) defined the SC adaptability as the ability of the SC to adapt its strategies, products and/or technologies to structural changes in the market. In addition, the previous literature established three main characteristics required to achieve SC adaptability: SC organizational design; use of technology; and medium- and long-term market knowledge (Arana-Solares et al., 2011; Lee, 2004, Tuominen et al., 2004; Tan and Tiong, 2005). These will therefore be the dimensions of SC adaptability considered in this study (see Table 2).

\begin{tabular}{|l|l|l|}
\hline Code & Variable and dimensions & Definition \\
\hline SC-Ad & Supply chain adaptability & $\begin{array}{l}\text { Ability to adapt strategies, products and/or technologies to } \\
\text { market structural changes. }\end{array}$ \\
\hline SC-Ad1 & $\begin{array}{l}\text { Organizational design of } \\
\text { the SC }\end{array}$ & $\begin{array}{l}\text { Ability to change supply chain processes and structure in line } \\
\text { with market changes. }\end{array}$ \\
\hline SC-Ad2 & Use of technology & $\begin{array}{l}\text { Ability to introduce new technologies in processes, products } \\
\text { and information systems based on the detection of } \\
\text { technological cycles. }\end{array}$ \\
\hline SC-Ad3 & $\begin{array}{l}\text { Medium- and long-term } \\
\text { market knowledge }\end{array}$ & $\begin{array}{l}\text { Ability to detect trends and possible medium- and long-term } \\
\text { changes in markets in which the SC operates. }\end{array}$ \\
\hline
\end{tabular}

Table 2. SC adaptability definitions and dimensions

\section{SC Alignment}

Alignment has been identified as an essential antecedent of firm performance and it is still a major challenge to achieve it in the SC (Skipworth et al., 2015). The alignment concept is applicable to different domains, as it is the basis of strategic and organizational alignment (Wu et al., 2014). Wong et al. (2012) have attributed poor business performance to a firm's failure to align internal SC processes with strategic goals. The literature distinguishes between internal or intra-organizational alignment and external or inter-organizational alignment (Attia, 2015). This study focuses on external alignment as it addresses relationships between the different SC partners. In relation to $\mathrm{SC}$ alignment, the SC should be considered as a whole, promoting 
customer focus, shared information between SC members, and joint management of business processes (Christopher, 2000; McAdam and McCormack, 2001). This holistic focus considers the SC as a single entity and not as separate companies that are pursuing their own objectives (Christopher and Towill, 2001; McAdam and McCormack, 2001; Lee, 2004). With this focus, SC alignment requires consistency of objectives, strategies, and processes among different SC partners to improve business competitiveness (Skipworth et al., 2015). In this context, van Hoek et al. (2001) stress that the alignment of SC members to make their operations as efficient as possible becomes a strategic factor for achieving CAs. Improving alignment between SC partners requires both the willingness to sacrifice short-term interests and widespread interfirm coordination (Kim et al., 2013).

In spite of the importance of the topic, very few studies have been found in the literature that analyze the relationship between SC alignment (as a single scale) and performance. Most research usually focuses on different dimensions of this variable. For example, SC information technology (IT) alignment along the SC has been analyzed as an independent scale in previous research, revealing a positive effect on: operational performance (e.g., Ye and Wang, 2013), market performance (e.g., Seggie et al., 2006), and customer value creation (e.g., Kim et al., 2013), but not on financial performance (e.g., Seggie et al,, 2006). Tan et al. (2010) distinguish between SC information alignment and SC relational alignment. Their results support information alignment having a positive impact on relational alignment, and relational alignment having a positive influence on firm performance (market share, return on assets, product quality, competitive position and customer service levels), but do not find support for a direct effect of information alignment on firm performance. Based on the theoretical framework developed by Wong et al. (2012), Skipworth et al. (2015) establish two types of SC alignment, shareholder and customer alignment, and analyze their separate effects on business performance. The results show that only customer alignment has a direct positive impact on business performance, while shareholder alignment is its antecedent.

Only a few papers have built the SC alignment construct as unidimensional (e.g., Dubey et al., 2015; Dubey and Gunasekaran. 2016) and multidimensional scales (e.g., Simatupang and Sridharan, 2005). Dubey et al. (2015) conclude that SC alignment is a powerful determinant of logistics performance and human performance and that leadership has a partial mediation effect between SC alignment and human performance. However, Dubey and Gunasekaran (2016) do not confirm the SC alignment - SC performance relationship. Simatupang and Sridharan (2005) confirm that SC alignment significantly influences fulfillment and inventory performance but not responsiveness performance. They find a positive effect of the alignment dimensions (information sharing, decision synchronization and incentive alignment) on different aspects of SC performance, such as, inventory, fulfillment and responsiveness performance.

Taking into account the previous research, Harris et al. (2010) state that a full understanding of the quantitative impacts of SC alignment has not been developed. SCM research lacks knowledge of exactly how SC alignment can be achieved and what business performance implications it has (Skipworth et al., 2015). Thus, more research has to be done into this topic. Again there is no consensus, so, the following hypothesis has been proposed in a positive sense in the search for new empirical evidence: 
SC alignment is a major emerging issue (Wong et al., 2012) but the current literature on SC alignment is both fragmented and largely theoretical in nature (Skipworth et al., 2015). SC alignment is the way in which operations and activities along the SC should be managed to meet product/market speed and complexity demands through the synchronization and coordination of operations (Kehoe et al., 2007). It is produced when information, responsibilities and roles, and incentives are shared among SC members in order to synchronize and coordinate processes and activities (Arana-Solares et al., 2012). When participants in an aligned SC are faced with either taking action that benefits their firm or taking action that benefits the chain, they choose the latter. SC alignment is the coordination of the interests of all the firms in an SC through: information and knowledge sharing; establishing roles, tasks and responsibilities; and sharing risks, costs, and rewards equitably (Arana-Solares et al., 2011; Simatupang and Sridharan, 2005; Piplani and Fu, 2005). Summarizing, the previous literature shows that for the SC to be aligned, information, process and incentive alignment have to be achieved (Lee, 2004; Kehoe et al., 2007; Tan et al., 2010; Arana-Solares et al., 2011). Therefore, these are the SC alignment dimensions considered in this research (see Table 3).

\begin{tabular}{|l|l|l|}
\hline Code & Variable and dimensions & Definition \\
\hline SC-Al & Supply chain alignment & $\begin{array}{l}\text { Ability for information and knowledge sharing, establishing } \\
\text { roles, tasks and responsibilities, and equitably sharing risks, } \\
\text { costs and benefits, with the aim of synchronizing and } \\
\text { coordinating processes and activities. }\end{array}$ \\
\hline SC-A11 & Incentive alignment & $\begin{array}{l}\text { Ability to clearly define the roles, tasks and responsibilities of } \\
\text { each member in chain processes to avoid any conflicts as far as } \\
\text { is possible. }\end{array}$ \\
\hline SC-A12 & Information alignment & $\begin{array}{l}\text { Ability to coordinate each partner's interests with the supply } \\
\text { chain's overall interests by defining relationships or agreements } \\
\text { in which risks, costs and benefits are equitably shared. }\end{array}$ \\
\hline
\end{tabular}

Table 3. SC alignment definitions and dimensions

\section{Triple-A SC}

There is a lack of agreement on the Triple A SC concept, on how firms could achieve Triple-A SC in practice and on its effects on performance. Arana-Solares et al. (2011) determine the dimensions and factors that characterize the Triple-A variables from a theoretical perspective.

Empirical research related to the Triple-A SC has been extremely scarce and only a few papers have been found. In most cases the Triple-A SC variables have been analyzed as individual independent unidimensional variables in the same framework (e.g., Dubey et al., 2015; Dubey and Gunasekaran, 2016). In the context of the humanitarian SC, Dubey et al. (2015) develop links between SC agility, adaptability and alignment and humanitarian SC performance. They find that SC agility fully mediates between SC adaptability and human performance and partially mediates between SC adaptability and logistics performance. For their part, Dubey and Gunasekaran (2016) explore possible linkages among the Triple-A SC variables as antecedents of humanitarian SC performance. They find that SC alignment is positively linked to SC agility and SC adaptability, and SC adaptability is positively linked to SC agility. Finally, only two articles, Whitten et al. (2012) and Attia (2015), have been found that analyze relationships between a Triple-A SC multidimensional construct and performance 
measures (neither analyses the effect of the individual variables on performance). Based on a survey of 132 APICS members, Whitten et al. (2012) conclude that Triple-A SC strategy positively impacts SC performance and that SC performance in turn positively affects organizational performance. As major limitations they stress that their data have been collected from single respondents and that their study is limited to a single country (USA) and call for further research to address these and other limitations. Attia (2015) examines the effect of Triple-A SC and marketing strategy alignment on SC performance (flexibility performance; resource performance; output performance) and organizational performance (strategic performance; operational performance), using data from 153 companies in the Egyptian textile industry. He concludes that Triple-A SC-marketing strategy alignment directly affects SC performance, and that SC performance positively affects organizational performance. He also concludes that further research is needed to test these results in different industrial sectors and countries and to analyze the effects of different environmental variables. Considering the Lee (2004) statement regarding Triple-A SC variables and the previous research, the following positive hypothesis is proposed with the aim of providing new empirical evidence on the topic:

\section{H4. Triple-A SC is positively related to $C A$}

\section{Methodology}

\section{Data collection}

The present study uses the International High Performance Manufacturing Project's current fourth round database (data collection completed in 2016) ${ }^{1}$. The basic technique that this research uses to obtain data is the survey, which has been an integral part of the HPM international project since its inception. The research conducted for the present study focuses on developed countries and its database was obtained from 151 manufacturing plants (with over 100 employees) in three industries (automotive components (44), electronics (42) and machinery (65)) in the 8 developed countries in the sample (UK (13), Germany (28), Japan (22), Sweden (9), Spain (25), Italy (29), Finland (17) and Austria (8)) on 2 continents. These industries were selected because their environments are characterized by intense global competition and because they are in transition (Ortega-Jimenez et al., 2015). The selection is limited to countries that were known for their strength in manufacturing. The unit of observation in the HPM project is the manufacturing plant rather than the company. This is because major differences may exist in, production practices, performance and contextual factors among plants belonging to the same company (Machuca et al., 2011). It was also established prior to the study that these plants were to have a minimum of 100 workers in order for there to be a sufficient number of managers to complete the survey (Morita et al., 2015). All plants within a given country are from different parent corporations.

The original survey items were based on a wide-ranging review of the prior Operations Management (OM) literature. A panel of experts reviewed the instruments in order to ensure content validity and a pilot test was conducted at several plants with pre-tests that had been

\footnotetext{
1 The HPM project's first round included 45 American- and Japanese-owned US plants in the automotive components, equipment/machinery and electronics sectors. Surveys began in 1989 and concluded in 1991. The questionnaires were modified and new countries (Canada, Germany, Japan, Italy and the United Kingdom) were added for the second round (1997-1999) in order to create an international database (Flynn et al., 1997). 164 plants in Asia (Japan), Europe (UK, Germany and Italy) and North America (US/Canada) were analyzed. Questionnaires were further updated in the third round (2006-2009) and data were taken from 266 plants in three industrial sectors (automotive components, equipment and electronics sectors) in ten different countries (Germany, Austria, Korea, US/Canada, Spain, Finland, Italy, Japan and Sweden).
} 
analyzed for reliability, validity and internal consistency. CA related items in the international HPM research questionnaires were reviewed during previous rounds. Validity, internal consistency and nomological validity constructs therefore presented good values in the scales that were finally used (Amahad and Schroeder, 2002; Cua et al., 2002; Schroeder and Flynn, 2001; Flynn, et al., 1995). Additional variables related to Triple-A SC constructs were added and validated in the fourth round (Marin-Garcia et al., forthcoming).

Each questionnaire in the research is tailored to the expertise of the focal informant following the key informant method (Bagozzi et al., 1991). The various measurement scales and objective questions are listed in 12 questionnaires directed at different managerial positions in the plant. They are all answered by 2 different managers in the post, except for the Plant Manager's, giving a total of 23 surveys per plant. Many of the measurement scales are included in at least two different questionnaires in order to enable information triangulation and to minimize variability caused by differences between individuals, thus guaranteeing greater instrument reliability. This gives a cross section of the plants and thus prevents individual bias (Van Bruggen et al., 2002; Sakakibara et al., 1997) whilst simultaneously improving validity. To this is added the fact (as already indicated above) that two people in each managerial position responds to each of the questionnaires. The items and questions that compose the scale are combined in different ways in each of the questionnaires in order to prevent any surveyee bias.

\subsection{Operationalization / Measures}

Items concerning SC agility (SC-Ag), adaptability (SC-Ad) and alignment (SC-Al) are measured using a 1-7 Likert scale with informants asked to indicate their degree of agreement (1 - strongly disagree, 4 - neither agree nor disagree, 7 - strongly agree). For each item, plantlevel data are calculated as an average value of all valid responses at the company. Triple-A SC dimensions and components are defined in Tables 1 to 3.

CA related items were measured on a 1-5 Likert scale with informants asked to give their perception of their past performance compared to their competitors' ( 1 - poor; 3 - average; 5 superior). This comparison with competitors allows us to obtain a measure of CA as perceived by managers, which is what is required to test the Triple-A SC - competitive advantage relationship. A list of items for each of the Triple-A and CA variables can be found in the Annex.

The SC agility, adaptability and alignment constructs were operationalized as composites (aggregate multidimensional construct) with each based on three dimensions, and these were the first order composites calculated from the measures taken from the questionnaires. Composites enable complex concepts (based on several developed items) to adapt to the theoretical aspects included in the construct (Sarstedt et al., 2016). In questionnaire design, each item represents a different aspect of the composite with which it is associated, meaning that items cannot be considered to be either redundant or replaceable by any other item inside that composite (Henseler, 2017). The Triple-A SC was modeled as a three-order composite (aggregate multidimensional construct).

CA was modeled by five dimensions (cost CA; quality CA; delivery CA; flexibility CA; and financial CA), which are analyzed as separate constructs. Except for delivery CA, which was estimated using a single item, all of these were operationalized as first order common factors 
estimated from the responses collected in the questionnaires. In CA dimensions, the scales used were designed and validated by other authors (Schroeder and Flynn, 2001; Flynn et al., 1995; Naor et al., 2010; Konecny, and Thun, 2011; Alfalla-Luque et al., 2012 and 2015) faithfully following authors' operationalizations, with each dimension's indicators chosen so as to be inter-correlated.

All the composites were estimated as Mode A ("correlation weights"), which provide better out-of-sample parameter estimations for composites and is more appropriate when, as is the case here, samples are mid-sized; moderate or low R2 values are expected; and the aim is to avoid the appearance of unexpected values (unexpected sign or non significant) due to suppression involving other predictors (Becker et al.; 2013; Henseler et al.,2016; Rigdon, 2012). Mode A also allows a better proxy for common factor estimations with partial least squares (PLS) when they are included with composites in the same model as, on the one hand, they are less affected by collinearity among indicators and, on the other hand, consistent partial least squares structural equation model (PLSc) can be applied in such a way that, starting with the PLS parameter estimation, an attenuation correction is applied to produce convergence to a common factor estimation (Becker et al., 2013; Rigdon, 2014).

The following are analyzed to assess the measurement and structural model: collinearity (VIF<3.3); significance (Bootstrap p-values) and relevance of the model's relationships; internal consistency $(>0.7)$, variance extracted $(>0.5)$ and discriminant validity for common factor constructs; level of R2 adjusted; size of f2 effect ( $<0.02$ no effect, 0.02-0.15 small, 0.15-0.35 medium, >0.35 large) (see Chin, 1998, Hulland, 1999, Hair et al., 2016). The two step method is used for higher order construct operationalization, with the first step being estimation of first order construct Latent Variable Scores (LVS) and the second step the use of standardized LVS as indicators for the higher order construct (see Edwards, 2001; Hair et al., 2016; Wilson, 2010).

A two step approach is followed to test Hypotheses 1 through 3. First, a global model with all questionnaire items is run. In this model the items are aggregated by nine dimensions of Triple-A SC variables. Each of the Triple-A SC variables is composed of three dimensions. In the second step, the LVS of composites obtained in step 1 are used to estimate SC-Ad, SC-Ag and SC-Al. These are used in three independent models which include only one Triple-A SC variable (Model 1 includes SC agility, Model 2 includes SC adaptability and Model 3 includes $\mathrm{SC}$ alignment) and the five dimensions of CA as first order constructs. Thus any suppression effects are avoided as the Triple-A SC dimensions will foreseeably be correlated.

The third step in the analysis is performed to test Hypothesis 4. First, the LVS are obtained for SC-Ad, SC-Ag and SC-Al and a prospective overall model used with the constructs from Step 2. Subsequently, a Higher Order Construct Triple-A SC is constructed (Model 4) based on the LVS of the Triple-A SC's variables and is related to the five CA dimensions as first order constructs (as the common factors are unspecified and their LVS cannot be calculated).

PLSc is used to test the Hypotheses. This is an appropriate method when the model contains exogenous constructs modeled as composites (see Henseler et al., 2016; Rigdon, 2012 and 2016, and Hair et al., 2016), and at the same time has endogenous constructs as common factors (Henseler et al., 2016; Rigdon, 2014; Dijkstra and Henseler, 2015). PLS have been used in OM and SCM research (Braunscheidel and Suresh, 2009; Blome et al., 2013; Skipworth et al., 2015; 
Kabra and Ramesh, 2016). To be precise, SmartPLS3 (Ringle et al., 2015) is used in conducting the analysis. The parameters used to perform the analysis all conform to the following values (Hair et al., 2016):

- PLSc algorithm, path weighting scheme, 300 iterations, stop criterion $10^{\wedge}-7$, pairwise deletion missing data.

- Consistent Bootstrap, 5000 subsamples, no sign changes.

\section{Results}

First, an analysis of the descriptive statistics will be done, paying close attention to missing values, skip patterns, range of response values, asymmetry and kurtosis (Hair et al. 2016). Most of the indicators present an average in the high part of the scale, all of the indicators present values as high as the maximum level of the scale and around half of indicators have the minimum level in the second level of the Likert scale. In general, sampled companies in developed countries present scores slightly toward the upper end of the scale (approaching a four on the 1 - 7 scale for Triple-A SC variables; and about three on the 1 - 5 scale for CA variables. Only one of the statistics for the item responses of the indicators (align31) presents kurtosis and skewness scores outside the range of -2 to +2 , which can be considered high for a normal distribution (Trochim, 2006; Viladrich Segués and Doval Dieguez, 2011).

There are no collinearity issues with the data. None of the indicators has a VIF value over 1.498 (VIF<3.3). Similarly, after the step 1 analysis, all the Triple-A SC composites are in a $1.99-1.15$ collinearity range (VIF<3.3).

Indicator significance and relevance are analyzed to evaluate the composite measurement model (Table 4). All the weights are significant except in three of the SC agility indicators (Agil11d, Agil23d and Agil31d) and two of the SC alignment indicators (Align21d and Align22d). Four of these have a loading of over 0.5 and Agil23 has a loading of 0.48 , very close to the threshold. Taken as a whole, the Triple-A SC composite measurement model is considered to be acceptable.

\begin{tabular}{|l|r|r|r|r|r|r|r|r|}
\hline & Weight & \multicolumn{1}{|c|}{ P Values } & $\mathbf{5 . 0 \%}$ & $\mathbf{9 5 . 0 \%}$ & \multicolumn{1}{l|}{ Loading } & P Values & $\mathbf{5 . 0 \%}$ & $\mathbf{9 5 . 0 \%}$ \\
\hline Agil11d->SC-Ag1 & 0.192 & 0.292 & -0.423 & 0.735 & 0.642 & 0.009 & 0.086 & 0.922 \\
\hline Agil12d->SC-Ag1 & 0.886 & 0.001 & 0.400 & 1.107 & 0.987 & 0.000 & 0.716 & 0.999 \\
\hline Agi121d->SC-Ag2 & 0.653 & 0.010 & 0.016 & 0.913 & 0.664 & 0.014 & -0.037 & 0.930 \\
\hline Agi122d->SC-Ag2 & 0.584 & 0.005 & 0.112 & 0.813 & 0.733 & 0.001 & 0.165 & 0.900 \\
\hline Agi123d->SC-Ag2 & 0.288 & 0.196 & -0.334 & 0.784 & 0.478 & 0.093 & -0.280 & 0.898 \\
\hline Agil31d->SC-Ag3 & 0.261 & 0.080 & -0.052 & 0.504 & 0.651 & 0.000 & 0.329 & 0.819 \\
\hline Agil32d->SC-Ag3 & 0.530 & 0.002 & 0.246 & 0.740 & 0.870 & 0.000 & 0.679 & 0.936 \\
\hline Agi133d->SC-Ag3 & 0.456 & 0.011 & 0.140 & 0.706 & 0.807 & 0.000 & 0.541 & 0.921 \\
\hline Adapt11d->SC-Ad1 & 0.758 & 0.000 & 0.556 & 0.937 & 0.934 & 0.000 & 0.819 & 0.989 \\
\hline Adapt12d->SC-Ad1 & 0.399 & 0.012 & 0.131 & 0.622 & 0.730 & 0.000 & 0.493 & 0.871 \\
\hline Adapt21d->SC-Ad2 & 0.680 & 0.000 & 0.434 & 0.955 & 0.901 & 0.000 & 0.757 & 0.991 \\
\hline Adapt22d->SC-Ad2 & 0.487 & 0.010 & 0.096 & 0.722 & 0.796 & 0.000 & 0.481 & 0.923 \\
\hline Adapt31d->SC-Ad3 & 0.663 & 0.000 & 0.470 & 0.829 & 0.893 & 0.000 & 0.771 & 0.960 \\
\hline Adapt32d->SC-Ad3 & 0.506 & 0.000 & 0.315 & 0.701 & 0.807 & 0.000 & 0.649 & 0.912 \\
\hline Align11d->SC-Al1 & 0.504 & 0.004 & 0.190 & 0.770 & 0.765 & 0.000 & 0.506 & 0.915 \\
\hline
\end{tabular}




\begin{tabular}{|l|r|r|r|r|r|r|r|r|}
\hline Align12d->SC-Al1 & 0.694 & 0.000 & 0.429 & 0.915 & 0.884 & 0.000 & 0.686 & 0.979 \\
\hline Align21d->SC-A12 & 0.400 & 0.077 & -0.131 & 0.793 & 0.520 & 0.029 & 0.046 & 0.853 \\
\hline Align22d->SC-A12 & 0.331 & 0.089 & -0.110 & 0.641 & 0.707 & 0.000 & 0.282 & 0.874 \\
\hline Align23d->SC-A12 & 0.662 & 0.002 & 0.224 & 0.915 & 0.838 & 0.000 & 0.391 & 0.959 \\
\hline Align31d->SC-A13 & 0.707 & 0.007 & 0.082 & 0.964 & 0.779 & 0.003 & 0.163 & 0.975 \\
\hline Align32d->SC-A13 & 0.629 & 0.009 & 0.128 & 0.962 & 0.708 & 0.003 & 0.218 & 0.972 \\
\hline X01d<-Cost-CA & 0.555 & 0.048 & 0.319 & 0.844 & 0.710 & 0.011 & 0.139 & 0.880 \\
\hline X02d<-Cost-CA & 0.376 & 0.031 & 0.050 & 0.670 & 0.481 & 0.015 & 0.163 & 0.869 \\
\hline X03d<-Cost-CA & 0.406 & 0.045 & -0.031 & 0.728 & 0.519 & 0.013 & 0.179 & 0.899 \\
\hline X04d<-Quality-CA & 0.528 & 0.000 & 0.350 & 0.785 & 0.678 & 0.049 & 0.478 & 1.044 \\
\hline X05d<-Quality-CA & 0.613 & 0.000 & 0.359 & 0.778 & 0.788 & 0.000 & 0.470 & 1.100 \\
\hline X06d<-Delivery-CA & - & - & - & - & - & - & - & - \\
\hline X07d<-Flexibility-CA & 0.595 & 0.000 & 0.432 & 0.763 & 0.717 & 0.000 & 0.511 & 0.943 \\
\hline X08d<-Flexibility-CA & 0.565 & 0.000 & 0.398 & 0.725 & 0.680 & 0.000 & 0.460 & 0.925 \\
\hline X09d<-Financial-CA & 0.454 & 0.000 & 0.275 & 0.612 & 0.627 & 0.000 & 0.372 & 0.828 \\
\hline X10d<-Financial-CA & 0.437 & 0.000 & 0.314 & 0.570 & 0.603 & 0.000 & 0.399 & 0.796 \\
\hline X11d<-Financial-CA & 0.424 & 0.000 & 0.246 & 0.582 & 0.586 & 0.000 & 0.317 & 0.806 \\
\hline
\end{tabular}

Table 4. Significance and relevance of indicators for composites

CA common factor construct indicator loadings have modest values (0.6 - 0.79) except for three indicators $(\mathrm{X} 02 \mathrm{~d}, \mathrm{X} 03 \mathrm{~d}$ and $\mathrm{X} 11 \mathrm{~d})$ with values of around 0.5 . Notwithstanding, all the loadings are significant. Reliability is modest (rho_A $=0.62-0.71$ ) and average variance extracted (AVE) is low (0.34 - 0.54). However, the CA scales pass the HTMT discriminant validity test. The endogenous construct can be accepted in overall terms as these are validated scales (Alfalla-Luque et al., 2015; Konecny and Thun, 2011; Morita et al., 2011; Naor et al., 2008; Hallgren and Alhager, 2009).

Having completed the three steps of the analysis, Table 5 summarizes correlations between the constructs in the proposed models. The majority are significant and in the moderate to low intensity range. SC agility is the construct with the least correlation with the others.

\begin{tabular}{|c|c|c|c|c|c|c|c|c|}
\hline & SC-Ag & SC-Ad & SC-Al & $\begin{array}{l}\text { Cost- } \\
\text { CA }\end{array}$ & $\begin{array}{l}\text { Quality- } \\
\text { CA }\end{array}$ & $\begin{array}{l}\text { Delivery- } \\
\text { CA }\end{array}$ & $\begin{array}{l}\text { Flexibility- } \\
\text { CA }\end{array}$ & $\begin{array}{l}\text { Financial- } \\
\text { CA }\end{array}$ \\
\hline Triple-A SC & --- & --- & ---- & $0.296^{* *}$ & $0.185^{*}$ & $0.211 * *$ & $0.356 * *$ & $0.515^{* *}$ \\
\hline SC-Ag & 1 & $0.414 * *$ & $0.249 * *$ & 0.128 & -0.147 & -0.054 & $0.256 * *$ & $0.177^{*}$ \\
\hline SC-Ad & & 1 & $0.425 * *$ & $0.186^{*}$ & 0.135 & $0.181 *$ & $0.268 * *$ & $0.379 * *$ \\
\hline SC-Al & & & 1 & $0.162 *$ & $0.231 * *$ & $0.227 * *$ & 0.127 & $0.240^{* *}$ \\
\hline Cost-CA & & & & 1 & $0.218 * *$ & $0.341 * *$ & $0.369 * *$ & $0.700^{* *}$ \\
\hline Quality-CA & & & & & 1 & $0.560 * *$ & 0.068 & $0.289 * *$ \\
\hline Delivery-CA & & & & & & 1 & $0.204 * *$ & $0.369 * *$ \\
\hline $\begin{array}{l}\text { Flexibility- } \\
\text { CA }\end{array}$ & & & & & & & 1 & $0.373 * *$ \\
\hline
\end{tabular}

Table 5. Significance level $* 5 \% ; * * 1 \%$. The first rows in the table come from step 3 and the last 7 rows come from step 2

SC agility (Model 1: Figure 1 and Table 6) explains a significant part of financial-CA $(\mathrm{R} 2 \mathrm{adj}=0.056)$ and of flexibility $\mathrm{CA}(\mathrm{R} 2 \mathrm{adj}=0.106)$ variance in the sample used. In both cases, 
the path is significant. In the former, the effect size makes a low contribution to R2 (f2=0.066), while the effect is moderate ( $\mathrm{f} 2=0.126$ ) in the latter. Even though, the SC agility effect is significant for these two constructs, the effect is only moderately relevant.

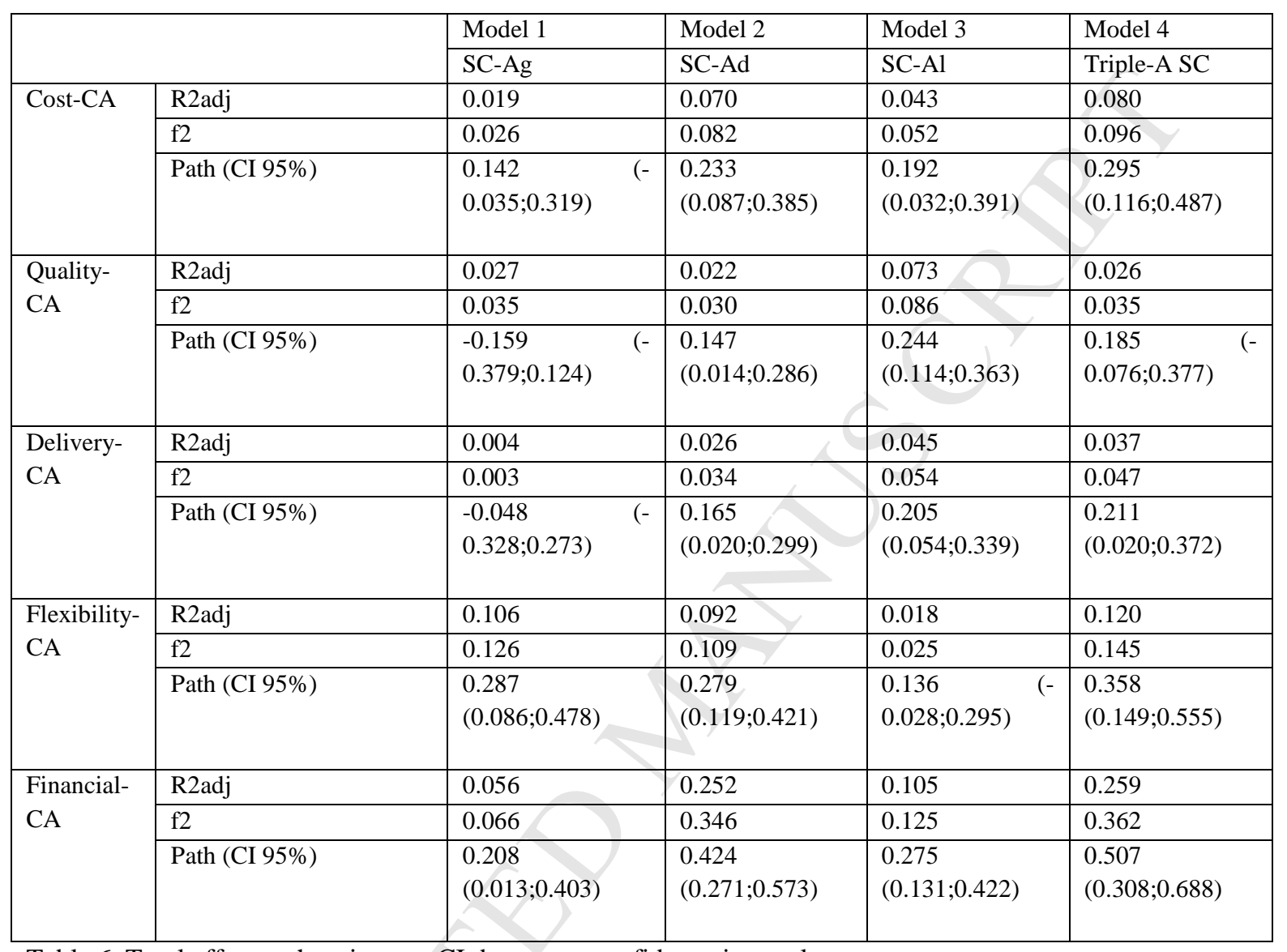

Table 6. Total effect path estimates. CI: bootstrap confidence interval 


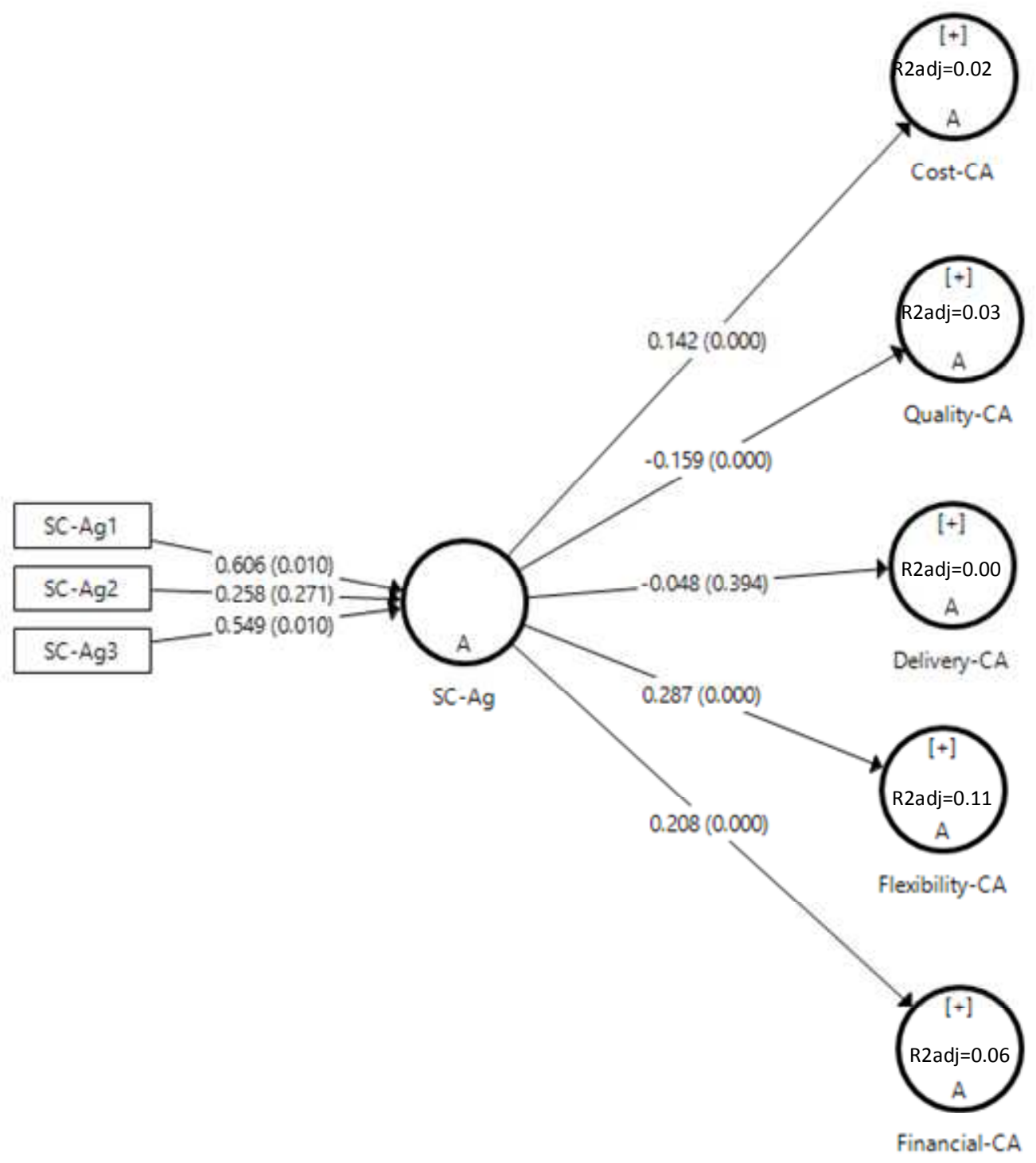

Figure 1. Standardized weights for Agility, path analysis and R2 adjusted for CA constructs (Model 1). One tailed bootstrap p-value at $5 \%$ in brackets.

SC adaptability (Model 2: Figure 2 and Table 6), however, has a substantial impact on several CA variables. Its paths are significant with all the endogenous constructs. The impact on financial-CA (R2adj= 0.252) stands out for its large contribution to effect size ( $\mathrm{f} 2=0.346$ ) and, to a lesser extent, the impact on flexibility-CA and cost-CA, with 0.09 and 0.07 R2adj respectively, although making only a moderate contribution, as shown by the $\mathrm{f} 2$ values (see Table 6). The effects on delivery-CA and quality-CA are less relevant but significant. 


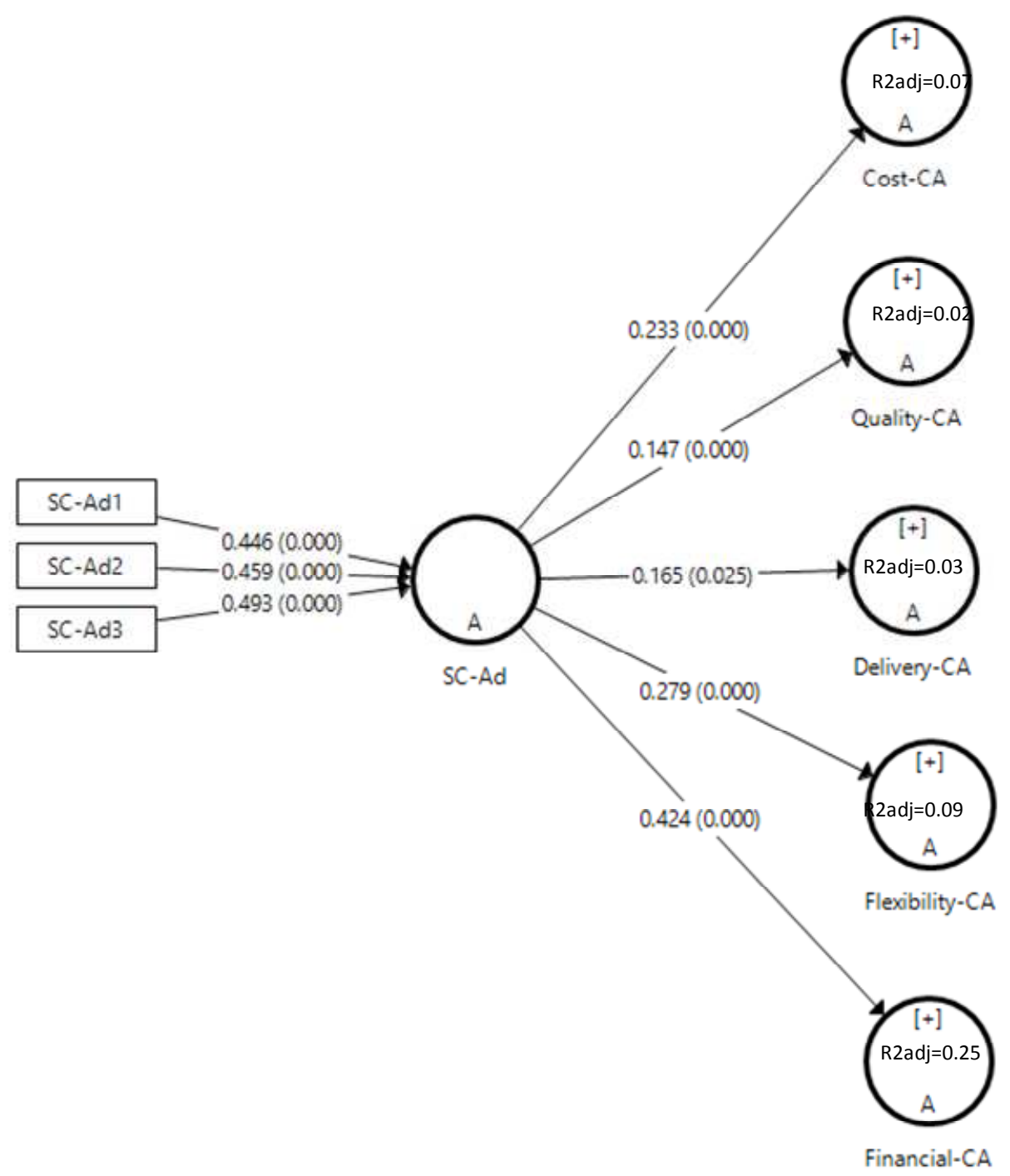

Figure 2. Standardized weights for Adaptability, path analysis and R2 adjusted for CA constructs (Model 2). One tailed bootstrap p-value at $5 \%$ in brackets.

For its part, SC alignment (Model 3: Figure 3 and Table 6) presents a positive, significant impact on all the constructs except one (flexibility-CA). The magnitude of the effect on financial-CA is moderate (explaining 10.5\% of this construct's variance). Despite its impact on the other three CA constructs being significant, it is low (0.07 R2adj in quality and 0.04 in the other two). 


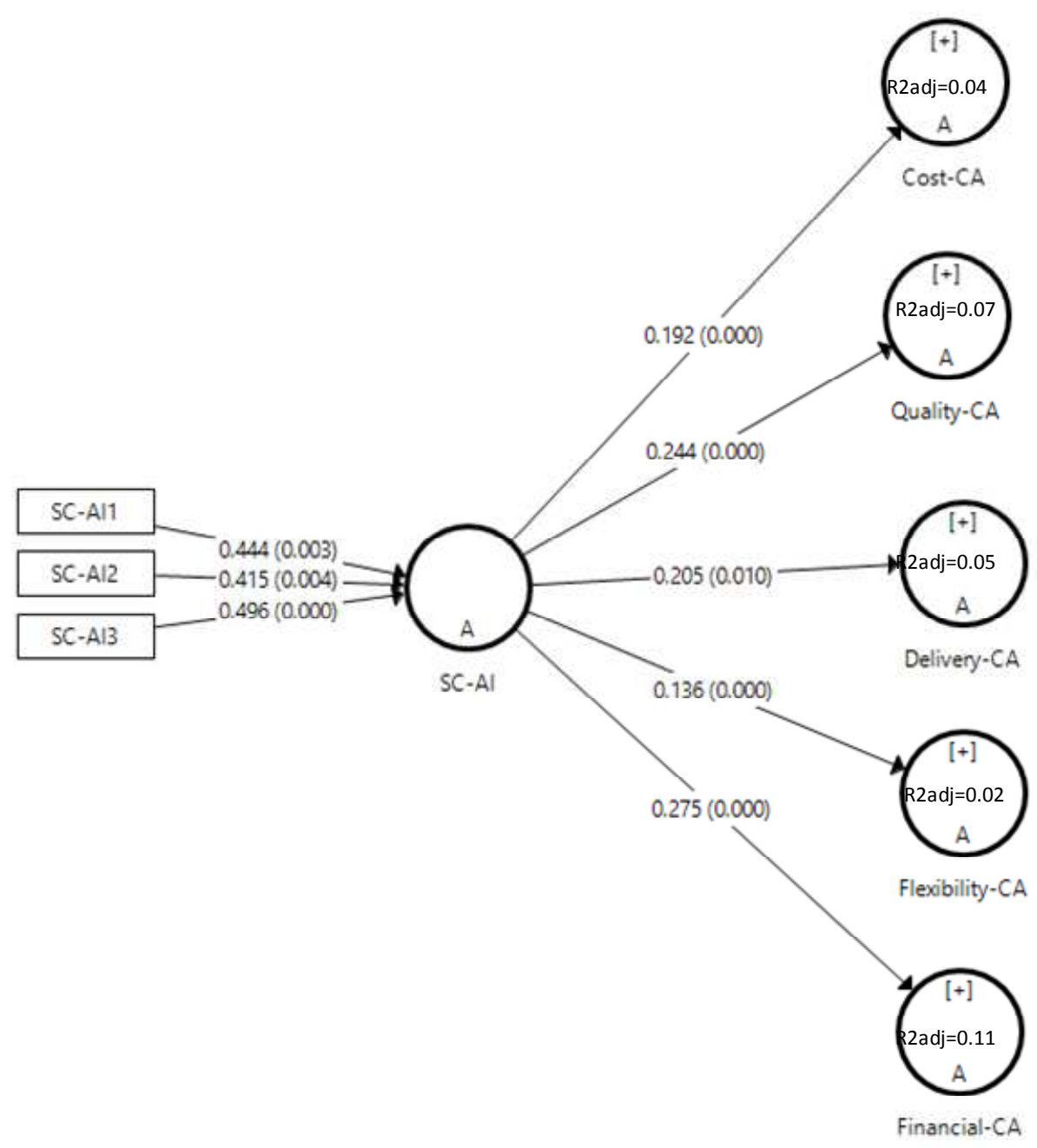

Figure 3. Standardized weights for Alignment, path analysis and R2 adjusted for CA constructs (Model 3). One tailed bootstrap p-value at $5 \%$ in brackets.

Lastly, if the joint effect of the three Triple-A SC dimensions is considered modeled as a third order construct (Model 4: Figure 4 and Table 6), a significant effect can be seen on all the endogenous constructs except quality-CA, for which the positive SC adaptability and SC alignment associations are negated by the neutral or negative SC agility effect. The most substantial effect is on financial-CA, with 0.259 R2adj (f2=0.362). The effect on SC flexibility is moderate ( $\mathrm{R} 2 \mathrm{adj}=0.120$ ), and although the effect on cost-CA and delivery-CA is significant, its relevance is low. As such, the Triple-A SC (Model 4) explains greater cost, financial and flexibility variance than the variables individually (Models 1, 2 and 3) and its f2 is higher. However, SC alignment (Model 3) explains more delivery-CA and quality-CA than Triple-A SC (Model 4). In summary, Triple-A SC improves a good number of the CAs. 


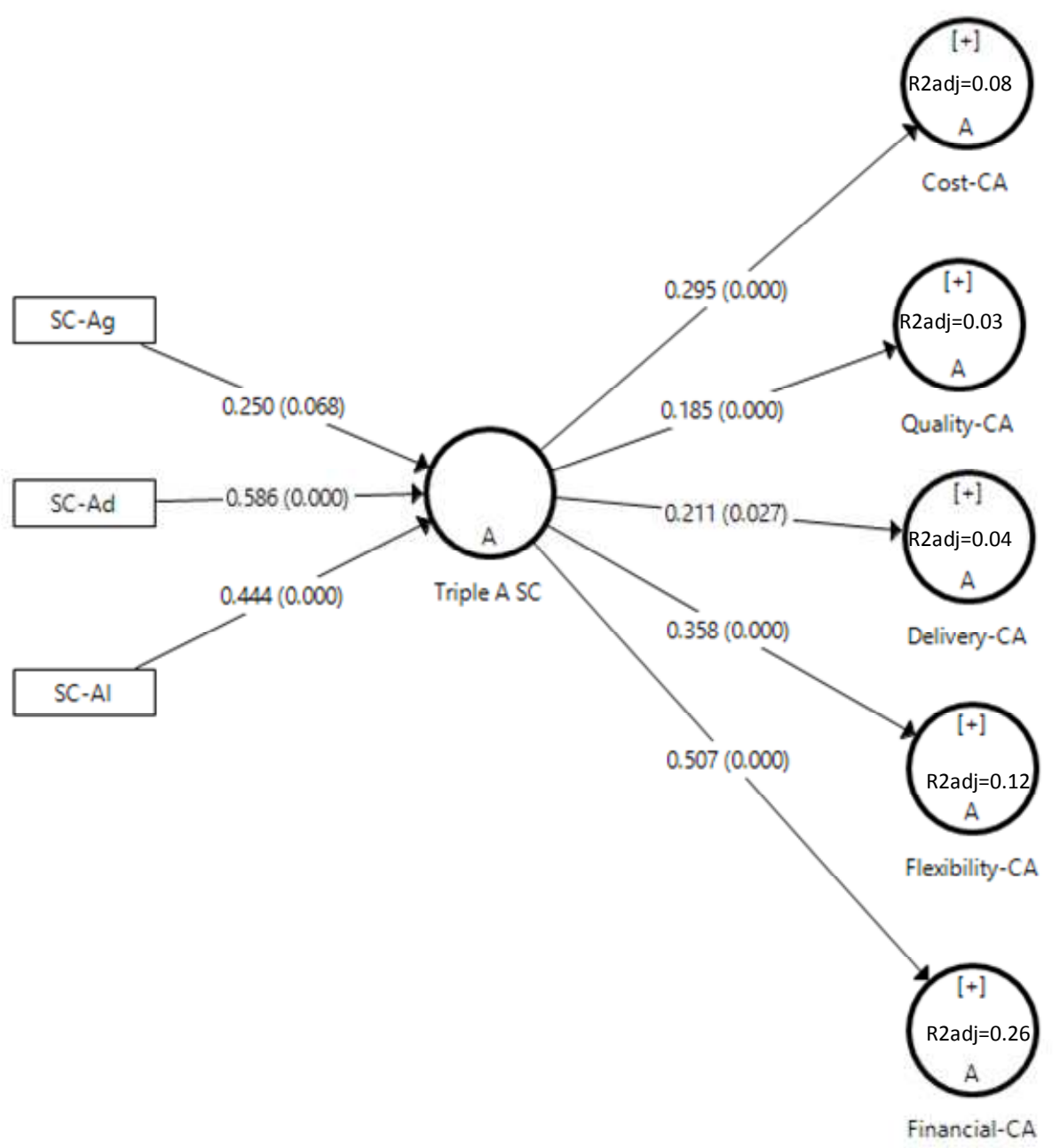

Figure 4. Standardized weights for Triple-A composite indicators and path analysis and R2 adjusted for CA constructs (Model 4). One tailed bootstrap p-value at 5\% in brackets.

To summarize the analyses: Hypothesis 2 has been fully confirmed by the proof of a significant, positive relationship between SC adaptability and all the CA dimensions. Hypotheses 3 and 4 have been mostly confirmed, as both SC alignment and Triple-A SC present significant relationships with four of the five studied CA dimensions. Hypothesis 1 has been partially confirmed, as significant relationships have only been found between SC agility and financial-CA and flexibility-CA.

When the effects of each of the Triple-A variables, on the various CAs are analyzed, different effects can be observed: SC adaptability is to a greater extent linked to financial-CA and flexibility-CA; SC alignment is linked to financial-CA and quality-CA and is most related to delivery-CA; and, finally, SC agility is most related to flexibility-CA. As for the Triple-A SC joint effect, this impact significant-on all the CA measures except quality. The strongest effects are produced on financial-CA and delivery-CA. Everything seems to indicate that SCs with high 
SC alignment, adaptability and agility provide better CA levels in this sample of developed countries.

\section{Discussion and conclusions}

Previous studies of Triple-A SC variables are few in number and, moreover, have for the most part been focused on the effect of these variables on different performance measures and not on the CA. The present study focuses on the effect of Triple-A variables on CA and contributes to filling this gap. The proposed model contributes to the literature with new evidence by analyzing a complex model that relates a set of variables that had never previously been studied jointly or in such great detail. Furthermore, the CA measures have also been analyzed independently and this enables the influence that SC agility, SC adaptability and SC alignment (individual effects) and Triple-A SC (cumulative joint effects) have on each measure to be seen, as well as more detailed results to be derived than if CAs were analyzed in aggregate terms. Individual variable effects are tested to determine whether they produce similar results that in the prior literature. However, previous studies do not analyze the various CA measures separately and they usually focus on performance measures.

In this study, SC agility has a significant effect on financial-CA and flexibility-CA but not on the other CAs. Some previous research studies were found that had detected a positive, direct impact of agility on performance measures (e.g., Blome et al., 2013; DeGroote and Marx, 2013; Eckstein et al., 2015; Gligor and Holcomb, 2012a; Swafford et al., 2008; Yusuf et al., 2014;), while others did not address this relationship (e.g. Gligor et al., 2015; Yang, 2014). The studies that have not confirmed this relationship have analyzed the performance measures in an aggregate way. For example, Yang (2014) analyzes performance as a scale that has items related to market share, return on assets, average selling price, overall product quality and customer service levels. Similarly, Um (2016) analyzes business performance as a scale composed of market share and sales growth, ROS and ROA measures. Other research has been focused on financial performance (ROA) (Gligor et al., 2015; Gligor 2016). Given the results of the present study, continuing to analyze the CAs individually would seem to be appropriate, as they have different effects that can lead to inappropriate conclusions if they are only analyzed using an aggregated single construct.

Notwithstanding, it can be stressed that some unexpected results have been obtained. Lee (2004) states: "most supply chains cope by playing speed against costs, but agile ones respond both quickly and cost-efficiently". So SC agility was expected to impact directly and positively on cost-CA and delivery-CA (as well as on quality-CA). There could be several explanations for the obtained result. First, this study focused on three mature sectors (automotive components, electronics and machinery), which were among the pioneers in the implementation of lean management. Lean management emphasizes reduction of waste, JIT deliveries and total quality management. This may imply that quality, delivery and cost are not generators of CAs in these sectors, but requirements of the industry. Firms in this sector have to have high levels in these indicators in order to survive in a very competitive environment. In other words, cost, delivery and quality could have become "order qualifiers" (a necessary condition for competition that should be present in almost all plants in developed countries) rather than "order winners" (a source of new improvements to CAs). Second, this research focuses on three mature sectors in developed countries. Despite the cultural differences that might exist among countries, any influence that they might have is mitigated by the fact that we are talking about a consolidated 
industrial fabric, with a broad, wide-ranging and long tradition in OM and SCM tools in companies. In addition, the global SC that these sectors are in means that production practices and tools are highly standardized. In this sense, for example, as Yusuf et al. (2014) assert for the case of agility: "agility is very much determined by the operating environment and the business sector or industry of the given SC".

SC adaptability has been found here to have a significant, positive effect on all CA measures (cost, quality, delivery, flexibility, and financial CAs). As a consequence, the relationship between SC adaptability and CA has been supported, in line with Schoenherr and Swink (2015) and Eckstein et al. (2015). Therefore, for this sample of developed countries, the positive effect of SC adaptability on all CA measures highlights the need for SC managers to manage SCs with a view to adaptation in the long term. This is in line with Lee (2004), who states that "efficient SCs often become uncompetitive because they do not adapt to changes in the structures of markets". The lack of research on this topic enhances the value of the evidence that has been found, as it is a starting point for further research.

This study also provides new empirical evidence of the relationship between SC alignment (as a single scale) and CA. A significant effect has been found for all CA measures used on this research except flexibility-CA, which was not confirmed. Using performance measures instead of CA measures, previous research on this topic found that SC alignment significantly influences fulfillment and inventory performance but not responsiveness performance (Simatupang and Sridharan, 2005). In the humanitarian context, SC alignment seems to be a determinant of logistics performance and human performance (Dubey et al., 2015) but not of humanitarian SC performance (Dubey and Gunasekaran, 2016). This study shows that SC alignment does not seem to have a significant effect on flexibility-CA, as a result of which any actions in this direction would not have a direct effect on changes in product mix and volume, which are seen to have greater links with SC agility and adaptability. SC alignment is oriented toward information, incentive and process alignment. Theoretically, SC agility should give greater support to flexibility-CA, as proven in the present research.

Furthermore, this paper provides interesting findings regarding the joint effect of SC agility, adaptability and alignment (Triple-A SC) on CAs. Previous researchers did not analyze the effect of the Triple-A SC on CAs but found Triple-A SC to have a positive impact on SC performance, measured as a single scale (Whitten et al., 2012; Attia, 2015). These studies included a number of limitations that have been overcome in the present research. In this study of developed countries, the joint effect of the Triple-A SC variables is significant on all the CA measures except quality. The strongest effects are on financial-CA and delivery-CA.

Lee (2004) points out that firms can build the Triple-A variables into SCs without having to make trade-offs. The obtained results go further, as they show that Triple-A SC variables are correlated, which implies that they support each other. Although each Triple-A SC variable has an individual effect on $\mathrm{CA}$, the results confirm that joint presence of all three variables reinforces and supports the obtention of CAs for most indicators. The joint Triple-A SC model is seen to have the greatest impact on financial-CA, flexibility-CA and cost-CA. However, the impact on quality-CA is once again shown not to be significant. As was commented with respect to SC agility, the fact that the firms in the sample are in mature sectors in developed countries might justify Triple-A SC's low impact on quality-CA, which could be considered an "order qualifier" found in industry as a whole. 
Moreover, important implications can be drawn from the results for managers, as the study shows which SC levers can be triggered to improve CA indicators. The results stress important aspects of SC strategy that should be considered when seeking a global CA. Practitioners could use the findings to focus their SC strategy to this end. First, it has been found that the Triple-A SC generates a broad range of CAs, especially in cost, financial proxy, and flexibility. As stated by Lee (2004) "only those companies that build agile, adaptable, and aligned supply chains get ahead of the competition".

However, if managers cannot completely achieve a Triple-A SC, the specific Triple-A SC variable that they should focus on will depend on the CAs that they are pursuing. For example, if they are interested in improving a financial-CA, they should develop SC adaptability. This implies improving the organizational design of the SC, the use of technology and medium- and long-term market knowledge. In addition, implementing practices that drive SC adaptability would have a clearer impact on most of the CA indicators. This emphasizes the importance of the company's long-term vision. SC strategy should adapt product and technologies to market structural changes. However, if the priority is to obtain a flexibility-CA, SC agility-related practices should be stressed. In this case, managers should focus on improving the short-term sensitivity to market and on the response to market changes through flexibility in volume and variety. Finally, alignment practices (information, incentive and process alignment) can also provide interesting results, especially for quality and delivery CA.

Researchers will find new data on the Triple-A SC and its relationship with CAs. The results represent a clear step forward in the topic and in SCM in general. This research is based on a powerful data set, which allows many of the limitations of previous studies to be overcome, including those linked to multiple-informant data gathering, the use of reliable multi-item scales and a by industry and by country sampling design. However, despite overcoming the limitations stated in previous studies, this study does have its own limitations, and these open up new research lines.

One limitation of this study is that the data are taken from three industries (electronics, machinery, and automotive components). The results should therefore be analyzed in the context of these sectors, and the results cannot be stated to be valid in other contexts. It would therefore be interesting to analyze the effect that the sector might have whenever the sample size allows it, as well as to extend the study to other sectors. Another limitation is that the results, obtained from plants in developed countries, may not be generalizable to all other countries. So, further research should include the extension of the analysed model to other areas, such as emerging countries, in order to determine whether there are any differences by type of country. Also, a wider sample would probably allow any cultural differences to be considered in greater depth. A further limitation is also shared with the majority of studies undertaken in the area: we use cross-sectional analysis and this does not give the opportunity to observe change, and reactions to change, in practice. A longitudinal study would allow the way that the variables evolve to be studied and so enable an analysis of the evolution of the levels of the variables and of the impact on CAs. This would allow us to determine whether Triple-A SCs have sustainable CAs, as was stated by Lee (2004). The database of the next round of the HPM project will hopefully enable this further research to be conducted. 
Apart from all the above, proposed further research could also address the following: First, the interaction effect between different pairs of Triple-A variables has not been explored in previous research but it might be interesting for this effect to be taken it into account in any further research. This would cover the whole array of possible relationships and provide us with a fully comprehensive analysis of the three variables that compose the Triple-A SC. Second, relationships among the Triple-A SC variables should be analyzed in order to develop new conceptual models that respond to the company's need to know which implementation patterns of different practices enable SC agility, adaptability and alignment to achieve the most efficient impact on CAs. Once the key drivers have been found, firms with limited resources will be able to improve their CAs.

\section{Acknowledgements (to be included in the final version)}

\section{References}

Agarwal, A., Shankar, R., Tiwari, M.K., 2006. Modeling the metrics of lean, agile and leagile supply chain: An ANP-based approach. Eur. J. Oper. Res. 173, 211-225. http://doi.org/10.1016/j.ejor.2004.12.005

Agarwal, A., Shankar, R., Tiwari, M. K. 2007. Modeling Agility of Supply Chain. Industrial Marketing Management 36(4), 443-57.

Ahmad, S., Schroeder, R. G., Mallick, D. N., 2010. The relationship among modularity, functional coordination, and mass customization: Implications for competitiveness. European Journal of Innovation Management, 13(1), 46-61.

Alfalla-Luque, R., Marín-García, J.A., Medina-Lopez, C., 2012. Is worker commitment necessary for achieving competitive advantage and customer satisfaction when companies use HRM and TQM practices? Universia Business Review, 36, 64-88.

Alfalla-Luque, R., Marin-Garcia, J.A., Medina-Lopez, C., 2015. An analysis of the direct and mediated effects of employee commitment and supply chain integration on organisational performance. Int. J. Production Economics, 162 (242-257). DOI: http://dx.doi.org/10.1016/j.ijpe.2014.07.004

Alfalla-Luque, R., Medina-Lopez, C., Dey, P.K., 2013. Supply chain integration framework using literature review. Production Planning and Control, 24(8-9), 800-817. http://doi.org/10.1080/09537287.2012.666870

Allred, C. R., Fawcett, S. E., Wallin, C., Magnan, G. M., 2011. A Dynamic Collaboration Capability as a Source of Competitive Advantage. Decision Sciences 42 (1), 129-161

Amahad, S., y Schroeder, R., 2002. Refining the product-process-matrix, International Journal of Operations \& Production Management, 22(1), 103-124.

Arana-Solares, I., Machuca, J.A.D., Alfalla-Luque, R., 2011. Proposed Framework for Research in the Triple A, Agility, Adaptability, Alignment) in Supply Chains. In Managing Global Supply Chain Relationships: Operations, Strategies and Practices, (306-321). IGI Global. Hershey, USA.

Asanuma, B., 1989. Manufacturer-Supplier Relationships in Japan and the Concept of Relation- Specific Skill, Journal of the Japanese and International Economies, 3(1), 1-30.

Attia, A., 2015. Testing the effect of marketing strategy alignment and Triple-A supply chain on performance in Egypt. EuroMed Journal of Business, 10(2), 163-180. http://doi.org/10.1108/EMJB-072014-0020

Bagozzi, R.P., Yi, Y. and Phillips, L.W., 1991. Assessing construct validity in organizational research, Administrative Science Quarterly, 36(3), 421-58.

Baker, P., 2008. The design and operation of distribution centres within agile supply chains. International Journal of Production Economics, 111(1), 27-41. http://doi.org/10.1007/s13398-014-0173-7.2

Barney, J., 1991. Firm resources and sustained competitive advantage. Journal of Management 17(1), 99120.

Barney, J.B., 2012. Purchasing, supply chain Management and sustained competitive advantage: The relevance of resource-based theory. Journal of Supply Chain Management, 48(2), 3-6.

Becker, J.M., Rai, A., Rigdon, E. E., 2013. Predictive validity and formative measurement in structural equation modeling: embracing practical relevance. In Thirty Fourth International Conference on Information Systems. Milan.

Blome, C., Schoenherr, T., Rexhausen, D., 2013. Antecedents and enablers of supply chain agility and its effect on performance: a dynamic capabilities perspective. International Journal of Production Research, 51(4), 1295-1318. http://doi.org/10.1080/00207543.2012.728011 
Bordoloi, S., Cooper, W., Matsuo, H., 1999. Flexibility, adaptability, and efficiency in manufacturing systems. Production and Operations Management. 8 (2), 133-150.

Bozarth, C. C., Warsing, D. P., Flynn, B.B., Flynn, E. J. 2009. The Impact of Supply Chain Complexity on Manufacturing Plant Performance. Journal of Operations Management 27 (1): 78-93

Braunscheidel, M. J., Suresh, N. C., 2009. The organizational antecedents of a firm's supply chain agility for risk mitigation and response. Journal of Operations Management, 27(2), 119-140. http://doi.org/10.1016/j.jom.2008.09.006

Brusset, X., 2016. Does supply chain visibility enhance agility? International Journal of Production Economics, 171, 46-59. http://doi.org/10.1016/j.ijpe.2015.10.005

Chan, H. K., Chan, F. T. S., 2010. Comparative study of adaptability and flexibility in distributed manufacturing supply chains. Decision Support Systems, 48(2), 331-341. http://doi.org/10.1016/j.dss.2009.09.001

Charles, A., Lauras, M., van Wassenhove, L. N., 2010. A model to define and assess the agility of supply chains: building on humanitarian experience. International Journal of Physical Distribution \& Logistics Management, 40(8/9), 722-741. http://doi.org/10.1108/09600031011079355

Chin, W.W., 1998. The partial least squares approach to structural equation modeling. In: G.A. Marcoulides, ed. Modern methods for business research (295-336). Mahwah: Lawrence Erlbaum Associates.

Christopher, M., 2000. The Agile Supply Chain: Competing in Volatile Markets. Industrial Marketing Management, 29(1), 37-44. http://doi.org/DOI: 10.1016/S0019-8501(99)00110-8

Christopher, M., and Towill, D., 2001. An integrated model for the design of agile supply chains. International Journal of Physical Distribution and Logistics Management, 31(4), 235-246.

Cousins, P.D., Menguc, B., 2006. The implications of socialization and integration in supply chain management, Journal of Operations Management, 24(5), 604-620.

Cua, K., Ketokivi, M., Schroeder, R., 2002. A perceptual measure of the degree of development of proprietary equipment, Structural Equation Modeling, 9 (4), 579-598.

DeGroote, S. E., Marx, T. G., 2013. The impact of IT on supply chain agility and firm performance: An empirical investigation. International Journal of Information Management, 33(6), 909-916. http://doi.org/10.1016/j.ijinfomgt.2013.09.001

Defee, C.C., Williams, B., Randall, W.S., Thomas, R., 2010. An inventory of theory in logistics and SCM research. The International Journal of Logistics Management, 21(3), $404-489$.

Dijkstra, T. K., Henseler, J., 2015. Consistent partial least squares path modeling. MIS quarterly, 39(2), 297-316.

Dyer, J.H., 1996. Specialized Supplier Networks as a Source of Competitive Advantage: Evidence from the Automotive Industry, Strategic Management Journal, 17, 271-92.

Dubey, R., Singh, T., Gupta, O.K., 2015. Impact of Agility, Adaptability and Alignment on Humanitarian Logistics Performance: Mediating Effect of Leadership. Glob. Bus. Rev. 16, 812-831. doi:10.1177/0972150915591463

Dubey, R., Gunasekaran, A., 2016. The sustainable humanitarian supply chain design: agility, adaptability and alignment. Int. J. Logist. Appl. 19, 62-82. doi:10.1080/13675567.2015.1015511

Eckstein, D., Goellner, M., Blome, C., Henke, M., 2015. The performance impact of supply chain agility and supply chain adaptability: the moderating effect of product complexity. International Journal of Production Research, 53(9-10), 3028-3046.

Edwards, J. R., 2001. Multidimensional Constructs in Organizational Behavior Research : An Integrative Analytical Framework. Organizational Research Methods, 4(2), 144-192.

Flynn, B.B., Sakakibara, S., Schroeder, R.G., 1995. Relationship between JIT and TQM: Practices and Performance, Academy of Management Journal, K, 38, 5), 1325-1360.

Flynn, B.B., Huo B., Zhao X., 2010. The impact of supply chain integration on performance: A contingency and configuration approach, Journal of Operations Management, 28, 58-71.

Ganguly, A., Nilchiani, R., Farr, J. V., 2009. Evaluating agility in corporate enterprises. International Journal of Production Economics, 118(2), 410-423. http://doi.org/10.1016/j.ijpe.2008.12.009

Gibbons, P., Kennealy, R., Lavin, G., 2003. Adaptability and Performance Effects of Business Level Strategies: an Empirical Test. Irish Marketing Review, 16(2), 57-64.

Gligor, D. M., Holcomb, M. C., 2012a. Antecedents and Consequences of Supply Chain Agility: Establishing the Link to Firm Performance. Journal of Business Logistics, 33(4), 295-308. http://doi.org/10.1111/jbl.12003

Gligor, D. M., Holcomb, M. C., 2012b. Understanding the role of logistics capabilities in achieving supply chain agility: a systematic literature review. Supply Chain Management-An International Journal, 17(4), 438-453. http://doi.org/10.1108/13598541211246594

Gligor, D. M., Holcomb, M., 2014. The road to supply chain agility: an RBV perspective on the role of 
logistics capabilities. International Journal of Logistics Management, 25(1), 160-179. http://doi.org/10.1108/IJLM-07-2012-0062

Gligor, D. M., Esmark, C. L., Holcomb, M. C., 2015. Performance outcomes of supply chain agility: When should you be agile? Journal of Operations Management, 33-34, 71-82. http://doi.org/10.1016/j.jom.2014.10.008

Gligor, D. M., 2016. The Role of Supply Chain Agility in Achieving Supply Chain Fit. Decision Sciences, 47(3), 524-553. http://doi.org/10.1111/deci.12205

Hair, J. F., Hult, G. T., Ringle, C. M., Sarstedt, M., 2016. A primer on partial least squares structural equation modeling, (PLS_SEM). 2nd edition. Thousand Oaks: Sage.

Hallgren, M., Olhager, J., 2009. Lean and agile manufacturing: External and internal drivers and performance outcomes. International Journal of Operations and Production Management, 29(10), 976999. http://doi.org/10.1108/01443570910993456

Harris, G. A., Componation, P. J., Farrington, P. A., 2010. An Exploration of Fisher's Framework for the Alignment of Supply Chain Strategy with Product Characteristics. EMJ-Engineering Management Journal, 22(4, SI), 31-42.

Hayes, R.H., Wheelwright, S.C., 1984. Restoring our Competitive Edge: Competing Through Manufacturing, United States. John Wiley \& Sons, New York, NY.

Henseler, J., Hubona, G., Ray, P. A., 2016. Using PLS Path Modeling in New Technology Research: Updated Guidelines. Industrial Management \& Data Systems, 116(1), 2-20. http://doi.org/10.1108/IMDS-09-2015-0382

Henseler, J., 2017. Bridging Design and Behavioral Research With Variance-Based Structural Equation Modeling. Journal of Advertising. Online publication. http://dx.doi.org/10.1080/00913367.2017.1281780

Hulland, J., 1999. Use of partial least squares (PLS) in strategic management research: a review of four recent studies. Strategic Management Journal, 20(2), 195-204.

Ismail, H.S., Sharifi, H., 2006. A balanced approach to building agile SCs. Int. J. Phys. Distrib. Logist. Manag. 36, 431-444. doi:10.1108/09600030610677384

Ivanov, D., Sokolov, B., Kaeschel, J., 2010. A multi-structural framework for adaptive supply chain planning and operations control with structure dynamics considerations. European Journal of Operational Research, 200(2), 409-420. http://doi.org/10.1016/j.ejor.2009.01.002

Kabra, G., Ramesh, A., 2016. Information Technology, Mutual Trust, Flexibility, Agility, Adaptability: Understanding Their Linkages and Impact on Humanitarian Supply Chain Management Performance. Risk Hazards Cris. Public Policy 7, 79-103. doi:10.1002/rhc3.12096

Katayama, H., Bennett, D., 1999. Agility, adaptability and leanness: A comparison of concepts and a study of practice. International Journal of Production Economics, 60-61, 43-51. http://doi.org/DOI: 10.1016/S0925-5273(98)00129-7

Kehoe, D. F., Dani, S., Sharifi, H., Burns, N. D., Backhouse, C. J., 2007. Demand network alignment: aligning the physical, informational and relationship issues in SCs. International Journal of Production Research, 45(5), 1141-1160. http://doi.org/10.1080/00207540600635219

Ketchen, D. J., Hult, G. T. M., 2007. Bridging organization theory and supply chain management: The case of best value SCs. Journal of Operations Management, 25(2), 573-580. http://doi.org/10.1016/j.jom.2006.05.010

Khan, A. K., Pillania, R. K., 2008. Strategic sourcing for supply chain agility and firms' performance A study of Indian manufacturing sector. Management Decision, 46(10), 1508-1530. http://doi.org/10.1108/00251740810920010

Kim, D., Cavusgil, S.T., and Cavitsgil, E., 2013. Does IT Alignment between Supply Chain Partners Enhance Customer Value Creation? An Empirical Investigation, Industrial Marketing Management 42(6):880-89

Konecny, P.A., Thun, J.H., 2011. Do it separately or simultaneously - An empirical analysis of a conjoint implementation of TQM and TPM on plant performance. International Journal of Production Economics, 133, 496-507. doi:10.1016/j.ijpe.2010.12.009

Lee, H.L., 2004. The Triple-A supply chain. Harvard Business Review, 82, 10, 102-112.

Li, X., Chung, C., Goldsby, T. J., Holsapple, C. W., 2008. A unified model of supply chain agility: the work-design perspective. International Journal of Logistics Management, 19(3), 408-435. http://doi.org/10.1108/09574090810919224

Li, X., Goldsby, T. J., and Holsapple, C. W., 2009. Supply chain agility: scale development. International Journal of Logistics Management, 20(3), 408-424. http://doi.org/10.1108/09574090911002841

Lin, C.-T., Chiu, H., Chu, P.-Y., 2006. Agility index in the supply chain. Int. J. Prod. Econ. 100, $285-299$. http://doi.org/10.1016/j.ijpe.2004.11.013

Liu, H., Ke, W., Wei, K. K., Hua, Z., 2013. The impact of IT capabilities on firm performance: The 
mediating roles of absorptive capacity and supply chain agility. Decision Support Systems, 54(3), 1452-1462. http://doi.org/10.1016/j.dss.2012.12.016

Machuca, J.A.D., Ortega-Jimenez, C.H., Garrido-Vega, P., and Perez-Diez-de-los Rios, J.L., 2011. Do technology and manufacturing strategy links enhance operational performance? Empirical research in the auto supplier sector. International Journal of Production Economics, 133, 541-550.

Marin-Garcia, J.A., Alfalla-Luque, R., Machuca, J.A.D., forthcoming. A Triple-A supply chain measurement model: validation and analysis, International Journal of Physical Distribution \& Logistics Management.

McAdam, R., McCormack, D., 2001. Integrating business processes for global alignment and supply chain management. Bus. Process Manag. J. 7, 113-130.

Mokadem, M. E., 2016. ISO 9000 moderation role over supply chain alignment in manufacturing context. Journal of Manufacturing Technology Management, 27(3), 338-363. http://doi.org/10.1108/JMTM03-2015-0015

Morita, M., Flynn, E. J., Ochiai, S., 2011. Strategic management cycle: The underlying process building aligned linkage among operations practices. International Journal of Production Economics, 133(2), 530-540. http://doi.org/10.1016/j.ijpe.2010.09.003

Morita, M., Machuca, J.A.D., Flynn, E.J., and Pérez-de-los-Ríos, J.L., 2015. Aligning product characteristics and the supply chain process - A normative perspective, International Journal of Production Economics, 161, 228-241

Naylor, J. Ben, Naim, M., Berry, D., 1999. Leagility: integrating the lean and agile manufacturing in the total supply chain. International Journal of Production Economics, 62, 107-118.

Naor, M., Goldstein, S. M., Linderman, K. W., \& Schroeder, R. G., 2008. The role of culture as driver of quality management and performance: Infrastructure versus core quality practices. Decision Sciences, 39(4), 671-702.

Naor, M., Linderman, K.W., Schroeder, R.G., 2010. The globalization of operations in Eastern and Western countries: Unpacking the relationship between national and organizational culture and its impact on manufacturing performance. J. Oper. Manag. 28, 194-205.

Ortega-Jimenez, C.H., Machuca, J.A.D., Garrido-Vega, P., Filippini, R., 2015. The pursuit of responsiveness in production environments: From flexibility to reconfigurability. International Journal of Production Economics, 163,157-172.

Peteraf, M.A., 1993. The cornerstones of competitive advantage: a resource-based view. Strategic Management Journal, 14(3), 179-191.

Piplani, R., Fu, Y., 2005. A coordination framework for supply chain inventory alignment. J. Manuf. Technol. Manag. 16, 598-614.

Power, D. J., Sohal, A. S., Rahman, S., 2001. Critical success factors in agile supply chain management an empirical study. International Journal of Physical Distribution and Logistics Management, 31(4), 247-265. http://doi.org/10.1108/09600030110394923

Prajogo, D., Huo, B. and Han, Z., 2012. The effects of different aspects of ISO 9000 implementation on key supply chain management practices and operational performance, Supply Chain Management: An International Journal, 17 (3), 306-322.

Reuter, C., Förstl, K. Blome, C., Hartmann, E., 2010. Sustainable Global Supplier Management: The Role of Dynamic Capabilities in Achieving Competitive Advantage. Journal of Supply Chain Management, $46(2), 45-63$.

Rigdon, E. E., 2012. Rethinking Partial Least Squares Path Modeling : In Praise of Simple Methods. Long Range Planning, 45(5-6), 341-358. http://doi.org/10.1016/j.lrp.2012.09.010

Rigdon, E. E. (2014). Rethinking Partial Least Squares Path Modeling: Breaking Chains and Forging Ahead. Long Range Planning, 47(3), 161-167. http://doi.org/10.1016/j.lrp.2014.02.003

Rigdon, E. E., 2016. Choosing PLS path modeling as analytical method in European management research: A realist perspective. European Management Journal, 34(6), 598-605. http://doi.org/10.1016/j.emj.2016.05.006

Ringle, C. M., Wende, S., Becker, J. M., 2015. Smartpls 3. Boenningstedt: SmartPLS GmbH. Available at http://www.smartpls.com

Sakakibara, S., Flynn, B.B., Schroeder, R.G., Morris, W.T., 1997. The Impact of Just-In-Time Manufacturing and its Infrastructure on Manufacturing Performance, Management Science, 43 (9), 1246-1257.

Sangari, M. S., Razmi, J., 2015. Business intelligence competence, agile capabilities, and agile performance in supply chain. An empirical study. International Journal of Logistics Management, 26(2), 356-380. http://doi.org/10.1108/IJLM-01-2013-0012

Sarstedt, M., Hair, J. F., Ringle, C. M., Thiele, K. O., Gudergan, S. P., 2016. Estimation issues with PLS and CBSEM: Where the bias lies! Journal of Business Research, 69(10), 3998-4010. 
http://doi.org/10.1016/j.jbusres.2016.06.007

Schroeder, R. G., Flynn, B. B., 2001. High Performance Manufacturing. Global perspectives. John Wiley and Sons, New York.

Schoenherr, T., Swink, M., 2015. The Roles of Supply Chain Intelligence and Adaptability in New Product Launch Success. Decision Sciences, 46(5), 901-936. http://doi.org/10.1111/deci.12163

Seggie, S. H., Kim, D., Cavusgil, S. T., 2006. Do supply chain IT alignment and supply chain interfirm system integration impact upon brand equity and firm performance? Journal of Business Research, 59(8), 887-895. http://doi.org/10.1016/j.jbusres.2006.03.005

Sherehiy, B., Karwowski, W., Layer, J. K., 2007. A review of enterprise agility: Concepts, frameworks, and attributes. International Journal of Industrial Ergonomics, 37(5), 445-460. http://doi.org/10.1016/j.ergon.2007.01.007

Simatupang, T., Sridharan, R., 2005. The collaboration index: a measure for supply chain collaboration. Int. J. Phys. Distrib. Logist. Manag., 35 (1), 44-62.

Skipworth, H., Godsell, J., Wong, C. Y., Saghiri, S., Julien, D., 2015. Supply chain alignment for improved business performance: an empirical study. Supply Chain Management-An International Journal, 20(5), 511-533. http://doi.org/10.1108/cadena de suministroM-06-2014-0188

Sonntag, V., 2003. The role of manufacturing strategy in adapting to technological change: IMS. Journal of Manufacturing Technology Management, 14(2), 312-323.

Swafford, P. M., Ghosh, S., Murthy, N., 2006. The antecedents of supply chain agility of a firm: Scale development and model testing. Journal of Operations Management, 24(2), 170-188. http://doi.org/10.1016/j.jom.2005.05.002

Swafford, P. M., Ghosh, S., Murthy, N., 2008. Achieving supply chain agility through IT integration and flexibility. International Journal of Production Economics, 116(2), 288-297. http://doi.org/10.1016/j.ijpe.2008.09.002

Tan, V., Tiong, T. N., 2005. Change Management in Times of Economic Uncertainty. Singapore Management Review, 27(1), 49-68.

Tan, K.C., Kannan, V.R., Hsu, C.C., Keong-Leong, G., 2010. Supply chain information and relational alignments: mediators of EDI on firm performance, International Journal of Physical Distribution and Logistics Management, 40 (5), 377-394.

Teece, D., 2007. Explicating Dynamic Capabilities: The Nature and Microfoundations of (Sustainable) Enterprise Performance, Strategic Management Journal, 28(13), 1319-1350

Teece, D.J., Pisano, G., and Shuen, A., 1997. Dynamic Capabilities and Strategic Management, Strategic Management Journal, 18(7), 509-53.

Trochim, W. M., 2006. The Research Methods Knowledge Base, 2nd Edition. Internet WWW page, at URL: <http://www.socialresearchmethods.net/kb/> (version current as of October 20, 2006). Retrieved 20 diciembre 2016.

Thun, J. H., 2008. Empirical analysis of manufacturing strategy implementation. International Journal of Production Economics, 113(1), 370-382. http://doi.org/10.1016/j.ijpe.2007.09.005

Tuan, L. T., 2016. Organisational Ambidexterity and Supply Chain Agility: The Mediating Role of External Knowledge Sharing and Moderating Role of Competitive Intelligence, International Journal of Logistics-Research and Applications 19(6):583-603.

Tse, Y. K., Zhang, M., Akhtar, P., MacBryde, J., 2016. Embracing supply chain agility: an investigation in the electronics industry. Supply Chain Management-An International Journal, 21(1), 140-156. http://doi.org/10.1108/cadena de suministroM-06-2015-0237

Tuominen, M., Rajala, A., Möller, K., 2004. How does adaptability drive firm innovativeness? Journal of Business Research, 57(5), 495-506. http://doi.org/DOI: 10.1016/S0148-2963(02)00316-8

Um, J., 2016. The Impact of Supply Chain Agility on Business Performance in a High Level Customization Environment, Operations Management Research 1-10. http://dx.doi.org/10.1007/s12063-016-0120-1.

Van Bruggen,G.H., Lilien,G.L., Kacker,M., 2002. Informants in organizational marketing research: why use multiple informants and how to aggregate responses. Journal of Marketing Research, 39 (4), 469478.

Van Hoek, R. I., Harrison, A., Christopher, M., 2001. Measuring agile capabilities in the supply chain. International Journal of Operations and Production Management, 21(1/2), 126-148. http://doi.org/10.1108/01443570110358495

Viladrich Segués, M. C., Doval Dieguez, E., 2011. Medición: Fiabilidad y validez. Bellaterra: Laboratori d'Estadística Aplicada i de Modelització (UAB).

Wei, H.-L., Wang, E. T. G., 2010. The strategic value of supply chain visibility: increasing the ability to reconfigure. European Journal of Information Systems, 19(2), 238-249. http://doi.org/10.1057/ejis.2010.10 
Wernerfelt, B., 1984. A Resource-Based View of the Firm. Strategic Management Journal, 5(April-June), 171-80.

Whitten, G. D., Green, K. W., Zelbst, P. J., 2012. Triple A supply chain performance. International Journal of Operations and Production Management, 32(1), 28-48. http://doi.org/10.1108/01443571211195727

Wilson, B., 2010. Using PLS to Investigate Interaction Effects Between Higher Order Branding Constructs. In V. E. Vinzi, W. W. Chin, J. Henseler, H. Wang (Eds.), Handbook of partial least squares: Concepts, methods and applications in marketing and related fields.(Springer Handbooks of Computational Statistics Series, Vol. II) (pp. 621-652). Berlin: Springer.

Wong, C., Skipworth, H., Godsell, J., Achimugu, N., 2012. Towards a theory of supply chain alignment enablers: a systematic literature review. Supply Chain Management-An International Journal, 17(4), 419-437. http://doi.org/10.1108/13598541211246567

Wu, T., Jim Wu, Y.-C., Chen, Y. J., Goh, M., 2014. Aligning supply chain strategy with corporate environmental strategy: A contingency approach. International Journal of Production Economics, 147(PART B), 220-229. http://doi.org/10.1016/j.ijpe.2013.02.027

Wu, K. J., Tseng, M. L., Chiu, A. S., Lim, M. K., 2017. Achieving competitive advantage through supply chain agility under uncertainty: A novel multi-criteria decision-making structure. International Journal of Production Economics, 190 (August), 96-107.

Ye, F., Wang, Z., 2013. Effects of information technology alignment and information sharing on supply chain operational performance. Computers and Industrial Engineering, 65(3), 370-377. http://doi.org/10.1016/j.cie.2013.03.012

Yusuf, Y. Y., Gunasekaran, A., Adeleye, E. O., Sivayoganathan, K., 2004. Agile supply chain capabilities: Determinants of competitive objectives. European Journal of Operational Research, 159(2), 379-392. http://doi.org/10.1016/j.ejor.2003.08.022

Yusuf, Y. Y., Gunasekaran, A., Musa, A., Dauda, M., El-Berishy, N. M., Cang, S., 2014. A relational study of supply chain agility, competitiveness and business performance in the oil and gas industry. International Journal of Production Economics, 147(B), 531-543. http://doi.org/10.1016/j.ijpe.2012.10.009

\section{Annex: Variables, dimensions and items of the Triple-A SC}

\begin{tabular}{|c|c|}
\hline Code & Variables/Dimensions/Items \\
\hline SC-Ag & $\begin{array}{l}\text { AGILITY } \\
\text { Adapted from: Agarwal et al. (2006), Arana-Solares et al. (2011); Charles et al., 2010; } \\
\text { Christopher (2000); Khan and Pillania, 2008; Lin et al. (2006); Lee (2004); van Hoek } \text { et al. } \\
\text { (2001); Yusuf } \text { et al., } 2004\end{array}$ \\
\hline SC-Ag1 & Short term sensitivity to market \\
\hline Agill1d & $\begin{array}{l}\text { The following applications communicate in real time: Supply chain applications with } \\
\text { internal application within our organization (such as enterprise resource planning). }\end{array}$ \\
\hline Agil12d & $\begin{array}{l}\text { The following applications communicate in real time: Customer relationship applications } \\
\text { with internal applications in our company. }\end{array}$ \\
\hline SC-Ag2 & Volume flexibility \\
\hline Agil21d & Our customers choose us because we deliver flexibly for their needs. \\
\hline Agil22d & $\begin{array}{l}\text { Our company strives to shorten supplier lead time, in order to avoid inventory and } \\
\text { stockouts. }\end{array}$ \\
\hline Agil23d & $\begin{array}{l}\text { Flexibility in response to requests for changes is a characteristic of our relationship with } \\
\text { our key suppliers. }\end{array}$ \\
\hline SC-Ag3 & Variety flexibility \\
\hline Agil31d & We can add product variety without sacrificing quality. \\
\hline Agil32d & We can easily add significant product variety without increasing cost. \\
\hline Agil33d & Our capability for responding quickly to customization requirements is very high. \\
\hline SC-Ad & $\begin{array}{l}\text { ADAPTABILITY } \\
\text { Adapted from: Arana-Solares et al. (2011); Katayama and Bennett (1999); Lee (2004); Tan } \\
\text { and Tiong (2005); Tuominen et al. (2004). }\end{array}$ \\
\hline SC-Ad1 & Organizational Design of the SC \\
\hline Adapt11d & Our production system is designed to accommodate changes in demand volume. \\
\hline Adapt12d & Our production system is designed to accommodate changes in production mix. \\
\hline SC-Ad2 & Use of technology \\
\hline Adapt21d & $\begin{array}{l}\text { We have a good understanding of where our production technology stands in terms of } \\
\text { technology life cycles. }\end{array}$ \\
\hline Adapt22d & Our plant remains at the leading edge of new technology in our industry. \\
\hline SC-Ad3 & Medium- and long-term market knowledge \\
\hline
\end{tabular}




\begin{tabular}{|c|c|}
\hline Adapt31d & We monitor economies around the world to detect potential new markets. \\
\hline Adapt32d & $\begin{array}{l}\text { We are concerned about the needs of both our immediate customers and our end } \\
\text { consumers. }\end{array}$ \\
\hline SC-Al & $\begin{array}{l}\text { ALIGNMENT } \\
\text { Adapted from: Arana-Solares et al. (2011); Kehoe et al. (2007); Lee (2004); Piplani and Fu } \\
\text { (2005); Simatupang and Sridharan (2005); Tan et al. (2010). }\end{array}$ \\
\hline SC-Al1 & Incentive alignment \\
\hline Align11d & $\begin{array}{l}\text { Our top managers repeatedly tell us that sharing supply chain risks and rewards with our } \\
\text { suppliers is critical to our plant's success. }\end{array}$ \\
\hline Align12d & Our supply chain members have clearly defined goals within our supply chain. \\
\hline SC-A12 & Information alignment \\
\hline Align21d & We emphasize openness of communication in collaborating with our customers. \\
\hline Align22d & We emphasize openness of communication in collaborating with our suppliers. \\
\hline Align23d & We should use unambiguous language and communication with our supply chain partners. \\
\hline SC-Al3 & Process alignment \\
\hline Align31d & Cooperating with our customers is beneficial to us. \\
\hline Align32d & Cooperating with our suppliers is beneficial to us. \\
\hline CA & $\begin{array}{l}\text { COMPETITIVE ADVANTAGE } \\
\text { Please, indicate your opinion regarding your plant compared to its competitors in the same } \\
\text { industry } \\
\text { Adapted from: Ahmad } \text { et al. (2010); Alfalla-Luque } \text { et al. (2012, 2015); Bozarth } \text { et al. } \\
\text { (2009); Konecny and Thun (2011); Morita } \text { et al. (2011); Naor } \text { et al. (2010); Thun (2008) }\end{array}$ \\
\hline Cost-CA & Cost \\
\hline X01d & Unit cost of manufacturing \\
\hline $\mathrm{X} 02 \mathrm{~d}$ & Inventory turnover \\
\hline X03d & Cycle time (from raw materials to delivery) \\
\hline Quality-CA & Quality \\
\hline $\mathrm{X} 04 \mathrm{~d}$ & Conformance to product specifications \\
\hline X05d & Product capability and performance \\
\hline Delivery-CA & Delivery \\
\hline X06d & On time delivery performance \\
\hline Flexibility-CA & Flexibility \\
\hline $\mathrm{X} 07 \mathrm{~d}$ & Flexibility to change product mix \\
\hline X08d & Flexibility to change volume \\
\hline Financial-CA & Financial \\
\hline X09d & Throughput: the rate at which the plant generates money through sales \\
\hline X10d & Inventory: raw materials, work-in-process and finished goods \\
\hline $\mathrm{X} 11 \mathrm{~d}$ & $\begin{array}{l}\text { Operating expense: funds spent to generate turnover, including direct labor, indirect labor, } \\
\text { rent, utility expenses and depreciation }\end{array}$ \\
\hline
\end{tabular}




\title{
Triple-A and competitive advantage in supply chains: empirical research in developed countries
}

\author{
Rafaela Alfalla-Luque (alfalla@us.es) ${ }^{1}$ \\ GIDEAO Research Group, Departmento de Economía Financiera y Dirección de \\ Operaciones, Universidad de Sevilla, Spain \\ José A. D. Machuca (jmachuca@us.es) \\ GIDEAO Research Group, Departmento de Economía Financiera y Dirección de \\ Operaciones, Universidad de Sevilla, Spain \\ Juan A. Marin-Garcia (jamarin@omp.upv.es) \\ ROGLE Research Group, DOE Universitat Politècnica de València, Spain
}

\section{Acknowledgements}

This study has been conducted within the frameworks of the following projects: 'Acción especial SGUIT-2015 (SBAPA2015-06) HPM-(Project 2015/148 U.S.)-Junta de Andalucía (Spain); PAIDI Excellence Project P08-SEJ-0384-Junta de Andalucía (Spain); and DPI2009-11148-Spanish National Program of Industrial Design and Production.

\footnotetext{
${ }^{1}$ Corresponding author: GIDEAO research group. Faculty of Economics and Business Administration. University of Seville. Avda. Ramón y Cajal, 1. 41005 Seville (Spain). Email: alfalla@us.es
} 
This article was pre-selected from the highest evaluated papers presented at the 5th World Conference on Production and Operations Management (P\&OM Havana 2016), co-organized by the European Operations Management Association (EurOMA), the Production and Operations Management Society (POMS) and the Japanese Operations Management and Strategy Association (JOMSA). The original paper has followed the standard review process for the International Journal of Production Economics and was managed by Afonso Fleury and Gerald Reiner, as co-Editors, and supervised by Peter Kelle (IJPE's Editor America). 